\title{
41. TRACE-ELEMENT GEOCHEMISTRY OF SEDIMENTS AND SULFUR ISOTOPE GEOCHEMISTRY OF FRAMBOIDAL PYRITE FROM SITE 795, LEG 127, JAPAN SEA ${ }^{1}$
}

\author{
Toshiyuki Masuzawa, ${ }^{2}$ Jitsuya Takada, ${ }^{3}$ and Rokuji Matsushita ${ }^{3}$
}

\begin{abstract}
Sixty sediment samples collected every $10 \mathrm{~m}$ from Holes 795A and 795B in the northern Japan Sea were analyzed for 27 major and trace elements using instrumental neutron activation analysis, and for total organic carbon (TOC), total nitrogen, and total sulfur (TS). Sulfur isotope ratio $\left(\delta^{34} \mathrm{~S}_{\mathrm{CDT}}\right)$ was measured on sedimentary framboidal pyrite isolated from sediments with a high sulfur content. The changes in redox condition of the bottom water of the sea are estimated from vertical variations of redox sensitive elements (TOC, TS, Mn, Sb, U, and As) and from TOC-TS and TS- $\delta^{34} \mathrm{~S}_{\mathrm{CDT}}$ relationships. These data were compared to those from a piston core (KH77-3-L4') collected near Site 795. The estimated changes in the redox condition are: a variation between less oxic and less euxinic in Units 5, 4B, 4A, and 3 (ca. 13-15 to 6-7 Ma); oxic but less so than that of the present Japan Sea with diagenetic sulfate reduction under very high biological productivity in Unit 2 (ca. 6-7 to $2.4 \mathrm{Ma}$ ); and a drastic variation between oxic, similar to the present bottom water, and euxinic, similar to that during the last glacial period in the sea, in Units IB (ca. 2.4-1.2 Ma) and 1A (ca. 1.2 Ma to the present).
\end{abstract}

\section{INTRODUCTION}

The Japan Sea is a marginal sea behind the Japanese island arc with an abyssal plain about $3,500 \mathrm{~m}$ deep. Deep and bottom waters of the sea are isolated from the open ocean by shallow sills with maximum depths of $10-135 \mathrm{~m}$. The deep and bottom waters are, however, almost uniform in salinity $(34.06 \%$ oo-34.08 \% $\%$ ), temperature $\left(0.0^{\circ}-0.4^{\circ} \mathrm{C}\right)$, and dissolved oxygen concentration $(5.0-5.8 \mathrm{ml} / \mathrm{L}$; Nitani, 1972). Thus, the present Japan Sea is highly oxic. A drastic environmental change through the last glacial period has been suggested by paleontological (e.g., Arai et al., 1981; Oba et al., 1991) and geochemical (Masuzawa and Kitano, 1983b, 1984; Masuzawa and Kusakabe, unpubl. data; Masuzawa et al., in press) studies of piston core samples. The drastic change has been thought to be due to changes in the hydrology of the sea related to those in climate and in sea level through the last glacial period. Appearance of $\mathrm{H}_{2} \mathrm{~S}$-bearing bottom waters during the last glacial period has been indicated by vertical profiles of total sulfur content (Masuzawa and Kitano, 1984) and sulfur isotope ratio of isolated framboidal pyrite (Masuzawa and Kusakabe, unpubl. data) in a piston core (KH77-3-L4') from the northern Japan Basin. Masuzawa et al. (in press) recognized a change between oxic and euxinic bottom waters from vertical profiles of redox-sensitive elements such as $\mathrm{Mn}, \mathrm{Ce}, \mathrm{Sb}, \mathrm{U}, \mathrm{As}, \mathrm{S}$, and $\mathrm{C}$ of the same piston core through the last glacial period.

The Black Sea and the Cariaco Basin are typical euxinic basins at the present time. Oxygen-deficient environments have been reported in the South Atlantic Ocean after its opening (e.g., Brumsack, 1980) and in the eastern Mediterranean Sea in the Pleistocene and Quaternary as evidenced by the deposition of sapropel layers (e.g., Cita and Grignani, 1982). Such drastic change in redox conditions of the bottom water could be expected from the geologic history of the Japan Sea. The aim of the present paper is to survey the general trend of the change in redox conditions of the bottom water of the sea since its birth. The authors have analyzed 60 sediment samples collected every $10 \mathrm{~m}$ from Site 795, which is near piston core $\mathrm{KH} 77-3-\mathrm{L}^{\prime}$, in the northern Japan Basin. We report major and trace-element contents measured by neutron activation analysis, as well as sulfur isotope

'Pisciotto, K. A., Ingle, J. C., Jr., von Breymann, M. T., Barron, J., et al., 1992. Proc. ODP, Sci. Results, 127/128, Pt. 1: College Station, TX (Ocean Drilling Program).

${ }^{2}$ Water Research Institute, Nagoya University, Nagoya 464-01, Japan.

${ }^{3}$ Research Reactor Institute, Kyoto University, Kumatori, Osaka 590-04, Japan. ratios of sedimentary pyrite isolated from these sediment samples. The changes in redox conditions of the bottom water of the sea since its birth are discussed based on the distributions of redox-sensitive elements and sulfur isotope ratios of sedimentary pyrite with reference to those data from the piston core.

\section{MATERIALS AND METHODS}

Sixty sediment samples were taken from split cores on board the JOIDES Resolution according to a routine sample spacing of ca. $10 \mathrm{~m}$ from Holes $795 \mathrm{~A}$ and $795 \mathrm{~B}\left(43.987^{\circ} \mathrm{N}, 138.967^{\circ} \mathrm{E}, 3,300 \mathrm{~m}\right.$ water depth). The samples were sealed in polyethylene bags, stored in a refrigerator, and brought to the shore-based laboratory. A part of each sample was vacuum-dried at $60^{\circ} \mathrm{C}$ and powdered in an agate mortar for chemical analysis.

Total organic carbon (TOC) and total nitrogen (TN) were determined using a Yanaco MTS-2 CHN analyzer after removal of carbonate carbon with dilute hydrochloric acid and vacuum-drying at $60^{\circ} \mathrm{C}$. Total sulfur (TS) was determined with a DIONEX QIC ion chromatograph after pressurized microwave digestion with hydrogen peroxide and leaching with $0.1 \mathrm{M} \mathrm{Na}_{2} \mathrm{CO}_{3}$ solution (Takamatsu and Kawashima, 1988; Kojima et al., 1988). TS content was corrected by subtracting the amount of pore-water sulfate contained in the dried sample, which was estimated from pore-water composition (Tamaki, Pisciotto, Allan, et al., 1990) and $\mathrm{Cl}$ content.

Instrumental neutron activation analysis (INAA; Koyama et al., 1987; Masuzawa et al., 1989; Masuzawa and Koyama, 1989) was performed using the KUR reactor of Kyoto University for the determination of 27 major and trace elements.

Stable sulfur isotope ratio of sedimentary pyrite was measured by the method of Masuzawa and Kusakabe (unpubl. data): A portion of wet sediment sample $(6-8 \mathrm{~g})$ with a TS content of ca. $>0.5 \%$ was suspended in $0.0025 \mathrm{M} \mathrm{Na}_{4} \mathrm{P}_{2} \mathrm{O}_{7}$ solution and the supernatant solution was discarded after a few hours. This process was repeated several times to remove most of the clay particles. The residue was treated with concentrated hydrofluoric acid and with $6 \mathrm{M}$ hydrochloric acid on a hot plate. It was then transferred to a glass vial and suspended in tetrabromoethane $(\mathrm{d}=2.98$ $\mathrm{g} / \mathrm{cm}^{3}$ ); the suspension was then centrifuged. Sedimentary pyrite was obtained in the fraction heavier than tetrabromoethane. About $10 \mathrm{mg}$ of dried pyrite was decomposed with aqua regia and dissolved in $0.1 \mathrm{M}$ hydrochloric acid. Then it was passed through a cation exchange column to remove iron, and sulfur was precipitated as barium sulfate. Sulfur isotope ratio was measured using the thermal decomposition method of 
barium sulfate (Yanagisawa and Sakai, 1983) with a SIRA-10 mass spectrometer, and expressed in the $\delta$ notation as per mil ( $\%$ oo ) deviation from that of troilite in Canyon Diablo meteorite (CDT).

Isolated pyrite grains were examined with an optical microscope and a Hitachi X-560 scanning electron microscope (SEM) in conjunction with an EDAX PV-9900 energy dispersive X-ray fluorescence analysis system (EDS).

The lithology of Site 795 described by Tada and Fijima (this volume) is as follows: Unit 1A, distinctly banded dark and light clay and silty clay (0-64.6 mbsf); Unit 1B, faintly banded dark and light clay and silty clay (64.6-142.2 mbsf); Unit 2, homogeneous diatom ooze and diatom clay (142.2-395 mbsf); Unit 3, rhythmical alternations of dark and light diatom silty clay or siliceous silty claystone with burrow cycles (395-525 mbsf); Unit 4A, rhythmical alternations of dark chert and light siliceous claystone (525-587 mbsf); Unit 4B, siliceous claystone with horizontal burrows (587-645 mbsf); Unit 5, claystone with faint lamination and horizontal burrows (645-684 mbsf); and basaltic sill and lava (684-762 mbsf). Opal-A/opal-CT and opal-CT/quartz boundaries were found at 325 and $471 \mathrm{mbsf}$, respectively, and the top of the base rock has an estimated age of 13.0-15.0 Ma (Tamaki, Pisciotto, Allan, et al., 1990).

\section{RESULTS AND DISCUSSION}

Analytical results of TOC, TN, C/N, TS, and 27 major and trace elements of 60 sediment samples from Site 795 are listed in Table 1. This table also includes $\delta^{34} \mathrm{~S}_{\mathrm{CDT}}$ data of sedimentary pyrite. Vertical profiles of $\mathrm{Al}, \mathrm{Fe}$, and $\mathrm{Cr}$ (Fig. 1), Th, Hf, and Cs (Fig. 2), Sc, La, and Ce (Fig. 3), Ba, Zn, and Co (Fig. 4), TOC, TS, and Mn (Fig. 5), and $\mathrm{Sb}, \mathrm{U}$, and As (Fig. 6) are shown in Figures 1-6 with the lithology described by Tada and Iijima (this volume). The shipboard results of
TOC and TS (Tamaki, Pisciotto, Allan, et al., 1990) are included in Figure 5.

\section{Al and Refractory Elements}

$\mathrm{Al}$ contents (Fig. 1) are relatively low in Unit 2 and very low at several layers. The low $\mathrm{Al}$ contents of Unit 2 and several layers are due to the high diatom contents of these layers (Tamaki, Pisciotto, Allan, et al., 1990). Vertical profiles of Th, Hf, Cs, Sc, La, and Ce (Figs. 2 and 3) are very similar to that of Al. These elements show a refractory nature, and are thought to be contained in aluminosilicate particles behaving similarly to $\mathrm{Al}$ (Masuzawa et al., 1989).

\section{TOC and TS}

TOC content varies remarkably in Units $1 \mathrm{~A}$ and $1 \mathrm{~B}(0.15 \%-4.31 \%)$, shows a relatively low value in Unit 2, and a slightly higher value in Units 3, 4A, 4B, and 5 (Fig. 5). The TS content is also highly variable in Units $1 \mathrm{~A}$ and $1 \mathrm{~B}(0.04 \%-9.34 \%)$, shows a moderate value in Unit 2 , and a slightly higher value in Units 3, 4A, 4B, and 5 (Fig. 5).

Sudden increases in the sulfur content of up to $5.0 \%$, mostly as framboidal pyrite, were found in a piston core near Site 795 in the

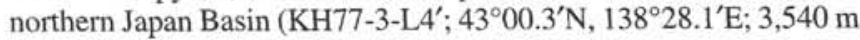
water depth; $528 \mathrm{~cm}$ long). This observation indicates the appearance of $\mathrm{H}_{2} \mathrm{~S}$-bearing (euxinic) bottom waters in the Japan Sea during the last glacial period (Masuzawa and Kitano, 1984). Core KH77-3-L4' is the only one without diagenetic sulfate reduction among 14 piston cores collected from the Japan Sea (Masuzawa and Kitano, 1983a; Masuzawa, 1987). The accumulation of sulfur as framboidal pyrite in areas without any hydrothermal activity is the result of microbial hydrogen sulfide via two possible ways: diagenetic sulfate reduction

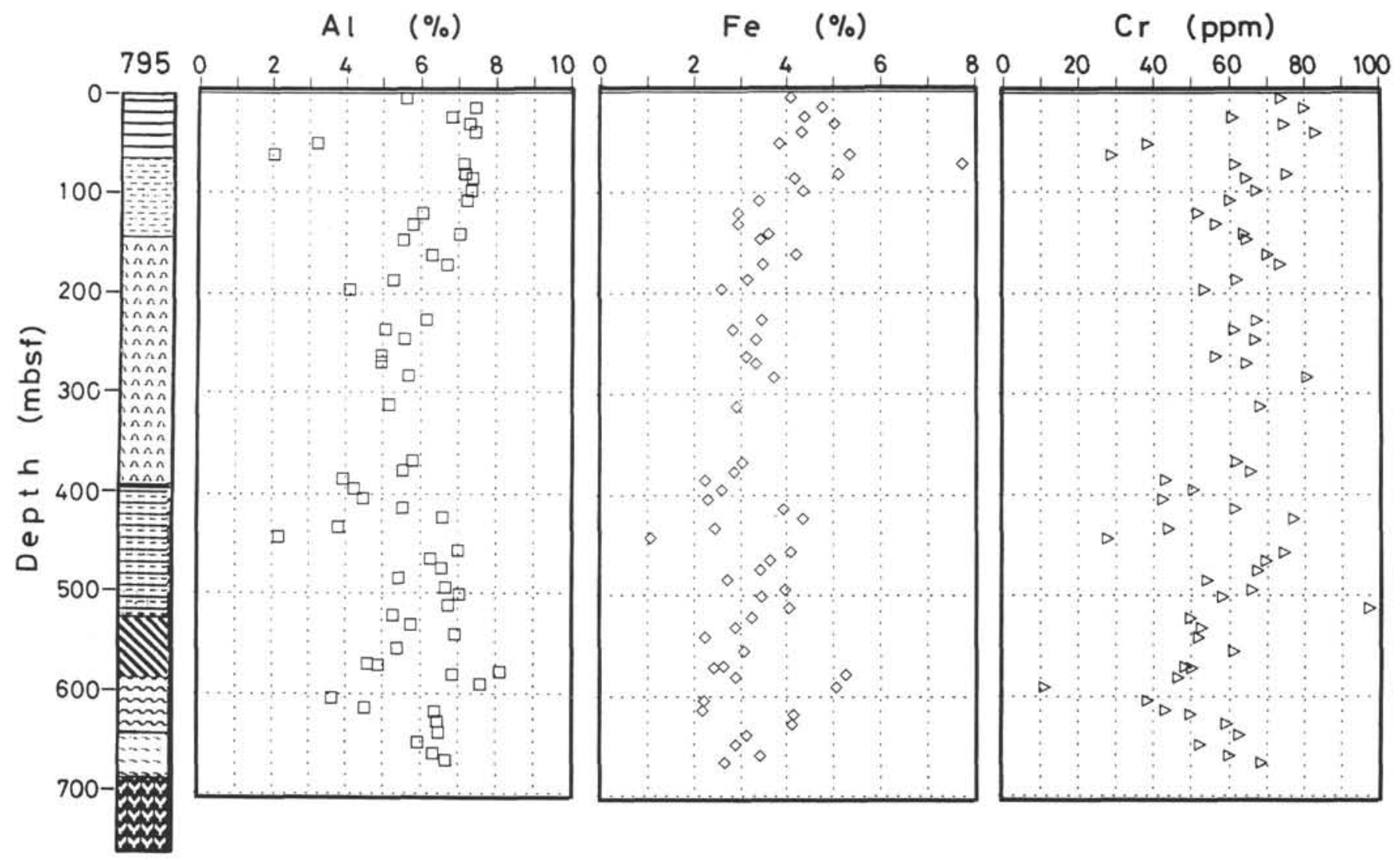

Figure 1. Vertical profiles of $\mathrm{Al}$ (left), $\mathrm{Fe}$ (middle), and $\mathrm{Cr}$ (right) at Site 795. The left-side column shows the lithology described by Tada and lijima (this volume): Unit 1A (0-64.6 mbsf), Unit 1B (64.6-142.2 mbsf), Unit 2 (142.2-395 mbsf), Unit 3 (395-525 mbsf), Unit 4A (525-587 mbsf), Unit 4B (587-645 mbsf), Unit 5 (645-684 mbsf), and basaltic sill and lava (684-762 mbsf). 


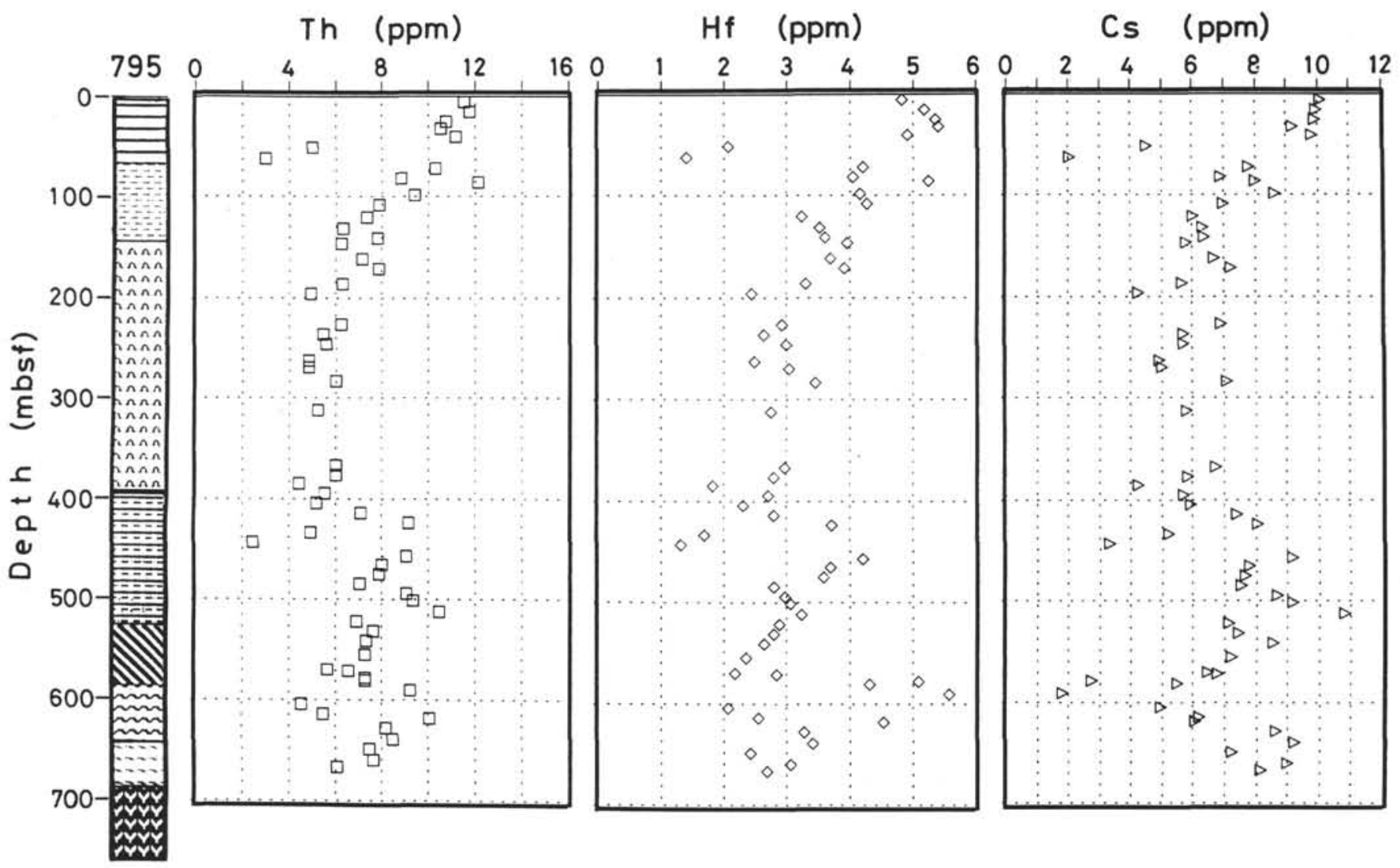

Figure 2. Vertical profiles of Th (left), Hf (middle), and Cs (right) at Site 795 (lithology as in Fig. 1).

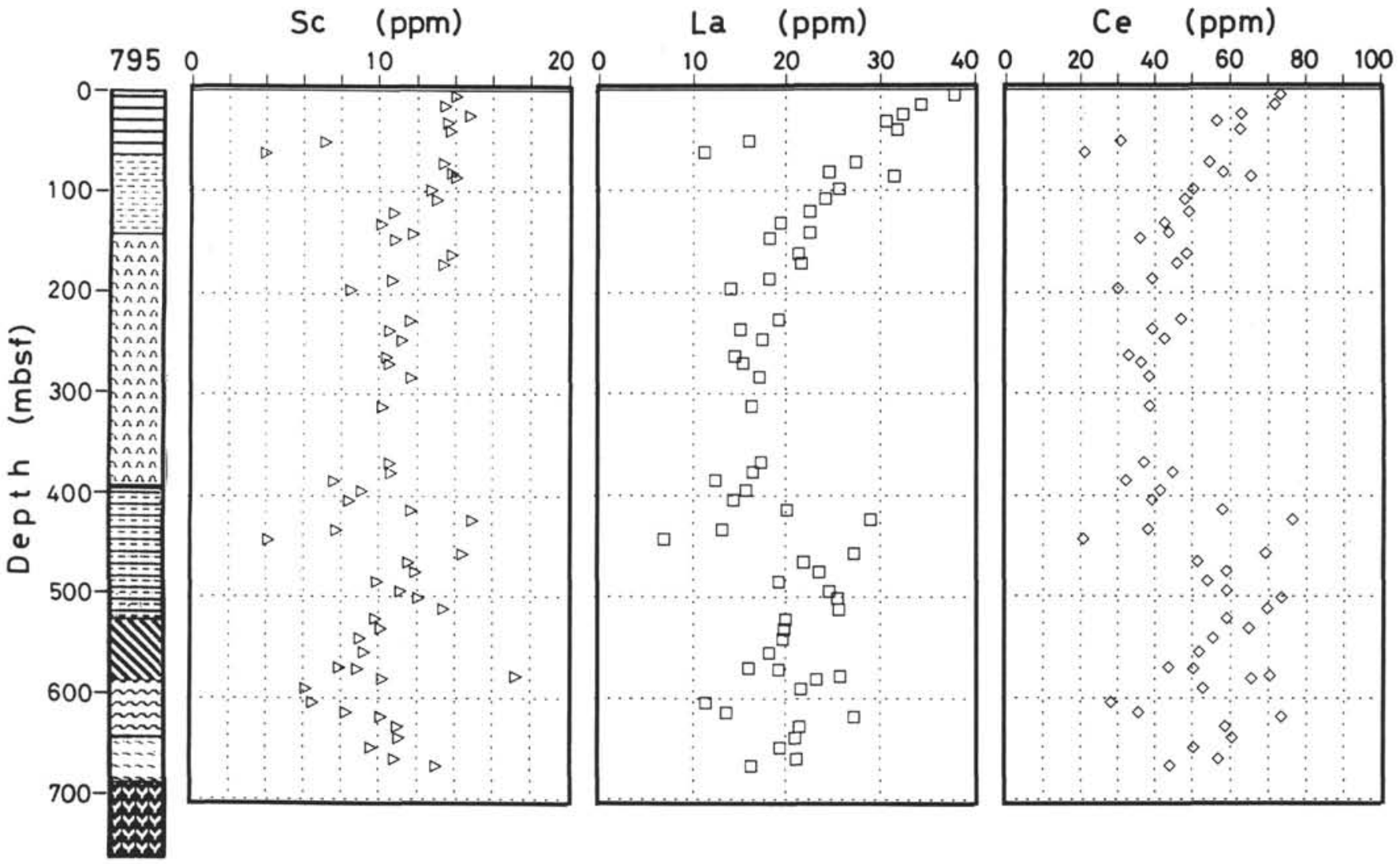

Figure 3. Vertical profiles of Sc (left), La (middle), and Ce (right) at Site 795 (lithology as in Fig. 1). 
Table 1. Sediment Chemistry at Site 795.

\begin{tabular}{|c|c|c|c|c|c|c|c|c|c|c|c|c|c|c|c|c|c|}
\hline \multirow{2}{*}{$\frac{\text { Hole }}{795 \mathrm{~A}}$} & \multicolumn{2}{|c|}{$\begin{array}{l}\text { Core, section } \\
\text { interval }(\mathrm{cm})\end{array}$} & \multirow{2}{*}{$\begin{array}{r}\begin{array}{r}\text { Depth } \\
\text { (mbsf) }\end{array} \\
5.34\end{array}$} & \multirow{2}{*}{$\begin{array}{c}\begin{array}{c}\text { TOC } \\
(\%)\end{array} \\
0.55\end{array}$} & \multirow{2}{*}{$\begin{array}{c}\begin{array}{l}\mathrm{TN} \\
(\%)\end{array} \\
0.087\end{array}$} & \multirow{2}{*}{$\frac{\mathrm{C} / \mathrm{N}}{6.4}$} & \multirow{2}{*}{$\begin{array}{l}\text { TS } \\
(\%) \\
0.07\end{array}$} & \multirow[t]{2}{*}{$\begin{array}{l}\delta^{34} S \\
(\% 00)\end{array}$} & \multirow{2}{*}{$\begin{array}{c}\begin{array}{c}\text { Al } \\
(\%)\end{array} \\
5.61\end{array}$} & \multirow{2}{*}{$\begin{array}{l}\mathrm{Fe} \\
(\%)\end{array}$} & $\begin{array}{l}\mathrm{Na} \\
(\%)\end{array}$ & $\begin{array}{c}\mathrm{Cl} \\
(\%)\end{array}$ & $\begin{array}{c}\mathrm{Mn} \\
(\mathrm{ppm})\end{array}$ & $\underset{(\mathrm{ppm})}{\mathrm{Br}}$ & $\underset{(\mathrm{ppm})}{\text { As }}$ & $\underset{(\mathrm{ppm})}{\mathrm{Sb}}$ & $\underset{(\mathrm{ppm})}{\mathrm{Zn}}$ \\
\hline & $01 \mathrm{H}-04$ & $84-86$ & & & & & & & & & 2.50 & 2.06 & 890 & 80 & 7.0 & 2.6 & 177 \\
\hline & $02 \mathrm{H}-05$ & $53-55$ & 15.83 & 0.52 & 0.070 & 7.4 & 0.06 & & 7.45 & 4.75 & 2.03 & 1.46 & 2740 & 53 & 9.5 & 4.2 & 171 \\
\hline & $03 \mathrm{H}-05$ & $39-41$ & 25.19 & 0.33 & 0.058 & 5.6 & 0.05 & & 6.81 & 4.38 & 2.92 & 2.94 & 3250 & 105 & 3.2 & 1.6 & 139 \\
\hline & $04 \mathrm{H}-03$ & $114-116$ & 32.44 & 1.00 & 0.117 & 8.6 & 3.13 & -40.7 & 7.32 & 5.03 & 2.12 & 1.56 & 760 & 63 & 88.6 & 11.2 & 181 \\
\hline & $05 \mathrm{H}-02$ & $83-85$ & 40.13 & 0.37 & 0.064 & 5.8 & 0.07 & & 7.45 & 4.30 & 2.26 & 1.79 & 1650 & 62 & 1.9 & 2.3 & 151 \\
\hline & $06 \mathrm{H}-03$ & $16-18$ & 50.46 & 3.14 & 0.254 & 12.4 & 3.84 & -41.8 & 3.22 & 3.83 & 2.51 & 3.11 & 900 & 156 & 56.9 & 10.0 & 43 \\
\hline & $07 \mathrm{H}-04$ & $39-41$ & 61.69 & 2.33 & 0.190 & 12.3 & 6.33 & -48.3 & 2.03 & 5.33 & 2.52 & 3.28 & 590 & 171 & 85.1 & 11.8 & \\
\hline & $08 \mathrm{H}-04$ & $59-61$ & 71.39 & 0.51 & 0.097 & 5.2 & 0.06 & & 7.15 & 7.72 & 2.37 & 2.07 & 1800 & 80 & 96.4 & 8.4 & 100 \\
\hline & $09 \mathrm{H}-04$ & $60-62$ & 80.90 & 0.26 & 0.057 & 4.6 & 0.04 & & 7.21 & 5.10 & 2.68 & 2.52 & 780 & 92 & 4.6 & 1.6 & 171 \\
\hline & $10 \mathrm{H}-01$ & $59-61$ & 85.89 & 0.28 & 0.072 & 3.8 & 0.05 & & 7.38 & 4.16 & 3.00 & 2.70 & 410 & 105 & 2.5 & 1.5 & 175 \\
\hline & $11 \mathrm{H}-03$ & $59-61$ & 98.39 & 0.29 & 0.068 & 4.3 & 0.61 & & 7.34 & 4.35 & 2.20 & 1.79 & 930 & 58 & 11.5 & 1.4 & 147 \\
\hline & $12 \mathrm{H}-03$ & $89-91$ & 108.19 & 0.40 & 0.077 & 5.2 & 0.10 & & 7.24 & 3.40 & 2.54 & 2.43 & 460 & 76 & $1>$ & 1.1 & 130 \\
\hline & $13 \mathrm{H}-05$ & $83-85$ & 120.63 & 0.69 & 0.095 & 7.2 & 0.14 & -38.3 & 6.05 & 2.94 & 2.44 & 2.13 & 970 & 79 & 4.9 & 3.9 & 175 \\
\hline & $14 \mathrm{H}-06$ & $84-86$ & 131.64 & 0.30 & 0.081 & 3.7 & 0.52 & -41.5 & 5.81 & 2.96 & 2.44 & 2.44 & 1870 & 95 & 7.0 & 5.5 & 212 \\
\hline & $15 \mathrm{H}-06$ & $83-85$ & 141.13 & 0.30 & 0.073 & 4.1 & 0.27 & & 7.05 & 3.61 & 2.64 & 2.48 & 1080 & 86 & 4.2 & 1.3 & 36 \\
\hline & $16 \mathrm{H}-04$ & $17-19$ & 146.97 & 0.65 & 0.097 & 6.6 & 0.84 & -32.7 & 5.54 & 3.41 & 2.39 & 2.05 & 940 & 82 & 8.8 & 3.2 & 157 \\
\hline & $18 \mathrm{H}-06$ & $85-87$ & 161.25 & 0.61 & 0.104 & 5.9 & 1.14 & 1.6 & 6.30 & 4.18 & 2.49 & 2.27 & 520 & 79 & 10.0 & 2.9 & 173 \\
\hline & $19 \mathrm{H}-06$ & $84-86$ & 170.74 & 0.57 & 0.102 & 5.7 & 1.03 & -12.1 & 6.70 & 3.48 & 2.59 & 2.35 & 670 & 81 & 6.0 & 2.2 & 179 \\
\hline & $21 X-04$ & $54-56$ & 186.64 & 0.72 & 0.096 & 7.6 & 0.91 & -13.1 & 5.28 & 3.17 & 2.63 & 2.54 & 590 & 99 & $1>$ & 3.4 & 163 \\
\hline & $22 \mathrm{X}-04$ & $53-55$ & 196.23 & 0.69 & 0.090 & 7.7 & 0.81 & -27.2 & 4.08 & 2.61 & 2.62 & 2.67 & 520 & 117 & 5.8 & 3.1 & 71 \\
\hline & $25 \mathrm{X}-05$ & $54-56$ & 225.85 & 0.43 & 0.079 & 5.5 & 0.76 & -23.7 & 6.16 & 3.46 & 2.62 & 2.44 & 760 & 87 & $1>$ & 2.0 & 133 \\
\hline & $26 \mathrm{X}-05$ & $54-56$ & 236.64 & 0.63 & 0.091 & 6.9 & 0.98 & -32.1 & 5.06 & 2.84 & 2.56 & 2.40 & 680 & 95 & 2.9 & 2.7 & 68 \\
\hline & $27 \mathrm{X}-05$ & $54-56$ & 246.44 & 0.65 & 0.108 & 6.1 & 0.97 & -8.0 & 5.56 & 3.34 & 2.44 & 1.71 & 710 & 84 & 4.1 & 2.6 & 57 \\
\hline & $29 \mathrm{X}-03$ & $17-19$ & 262.67 & 0.58 & 0.100 & 5.8 & 0.94 & -37.6 & 4.95 & 3.12 & 2.38 & 2.14 & 530 & 87 & 2.1 & 2.4 & 53 \\
\hline & $30 X-01$ & $55-57$ & 269.85 & 0.63 & 0.098 & 6.4 & 1.09 & -35.1 & 4.94 & 3.34 & 2.24 & 1.75 & 400 & 73 & 6.8 & 1.9 & 37 \\
\hline & $31 X-03$ & $56-58$ & 282.66 & 0.63 & 0.091 & 6.9 & 1.17 & -35.7 & 5.69 & 3.73 & 2.33 & 1.68 & 540 & 66 & 3.1 & 2.6 & 55 \\
\hline & $34 X-03$ & $58-60$ & 311.48 & 0.72 & 0.102 & 7.1 & 0.74 & -38.6 & 5.17 & 2.92 & 2.54 & 1.88 & 370 & 85 & 10.4 & 2.2 & 42 \\
\hline 795B & 01R-02 & $81-83$ & 367.51 & 0.41 & 0.066 & 6.1 & 0.54 & -23.8 & 5.78 & 3.05 & 1.47 & 0.68 & 350 & 27 & 4.8 & 1.4 & 35 \\
\hline & $02 R-02$ & $74-76$ & 377.24 & 0.66 & 0.082 & 8.1 & 1.00 & -44.4 & 5.52 & 2.85 & 1.37 & 0.59 & 410 & 36 & 8.1 & 3.0 & 52 \\
\hline & 03R-01 & $21-23$ & 384.91 & 0.96 & 0.077 & 12.4 & 0.97 & & 3.90 & 2.25 & 1.14 & 0.58 & 330 & 36 & 6.0 & 2.3 & 48 \\
\hline & $04 \mathrm{R}-01$ & $88-90$ & 395.28 & 0.58 & 0.057 & 10.2 & 0.97 & -41.3 & 4.22 & 2.60 & 1.18 & 0.54 & 310 & 34 & 7.2 & 2.6 & 40 \\
\hline & 05R-01 & $79-81$ & 404.89 & 0.51 & 0.067 & 7.7 & 0.82 & & 4.47 & 2.29 & 1.16 & 0.54 & 340 & 33 & 3.2 & 1.8 & 45 \\
\hline & 06R-01 & $81-83$ & 414.61 & 0.98 & 0.112 & 8.7 & 2.11 & -39.0 & 5.55 & 3.92 & 1.33 & 0.62 & 500 & 44 & 8.5 & 5.5 & 72 \\
\hline & 07R-01 & $56-59$ & 423.66 & 1.34 & 0.148 & 9.0 & 1.19 & -41.4 & 6.59 & 4.34 & 1.50 & 0.46 & 620 & 35 & 2.2 & 3.4 & 84 \\
\hline & 08R-01 & $92-94$ & 433.72 & 1.03 & 0.092 & 11.2 & 0.90 & -41.7 & 3.80 & 2.45 & 0.97 & 0.53 & 290 & 34 & 4.6 & 2.5 & 40 \\
\hline & 09R-01 & $120-122$ & 443.60 & 0.50 & 0.055 & 9.0 & 0.30 & -25.1 & 2.16 & 1.05 & 0.71 & 0.42 & 100 & 33 & 2.0 & i. 2 & 24 \\
\hline & 10R-04 & $36-36$ & 456.84 & 1.03 & 0.128 & 8.1 & 1.54 & -37.5 & 7.00 & 4.06 & 1.34 & 0.36 & 410 & 27 & 4.5 & 3.6 & 320 \\
\hline & $11 \mathrm{R}-03$ & $26-28$ & 464.96 & 0.61 & 0.100 & 6.0 & 1.87 & 14.2 & 6.26 & 3.64 & 1.51 & 1.05 & 410 & 43 & 3.0 & 2.5 & 180 \\
\hline & $12 \mathrm{R}-03$ & $27-29$ & 474.67 & 0.54 & 0.096 & 5.7 & 1.07 & -34.9 & 6.55 & 3.43 & 1.36 & 0.57 & 440 & 33 & 2.8 & 4.7 & 114 \\
\hline & 13R-03 & $27-29$ & 484.27 & 0.50 & 0.074 & 6.7 & 0.52 & -9.4 & 5.44 & 2.72 & 1.03 & 0.34 & 330 & 24 & 1.8 & 2.4 & 100 \\
\hline & $14 \mathrm{R}-03$ & $24-26$ & 493.94 & 0.63 & 0.097 & 6.6 & 2.27 & -32.4 & 6.68 & 3.97 & 1.13 & 0.50 & 290 & 34 & 10.4 & 3.6 & 122 \\
\hline & $15 \mathrm{R}-01$ & $148-150$ & 501.48 & 0.56 & 0.080 & 7.0 & 0.60 & -31.5 & 7.03 & 3.46 & 1.12 & 0.52 & 270 & 25 & 1.9 & 2.4 & \\
\hline & 16R-02 & $62-64$ & 511.82 & 0.91 & 0.117 & 7.8 & 1.24 & -28.8 & 6.74 & 4.03 & 1.09 & 0.40 & 270 & 36 & 8.3 & 2.9 & 84 \\
\hline & 17R-02 & $67-69$ & 521.57 & 0.64 & 0.079 & 8.1 & 2.10 & -33.1 & 5.29 & 3.25 & 0.92 & 0.43 & 460 & 27 & 3.1 & 4.0 & 243 \\
\hline & 18R-02 & $67-69$ & 531.27 & 1.20 & 0.114 & 10.5 & 1.23 & -20.8 & 5.74 & 2.88 & 1.01 & 0.61 & 240 & 39 & 9.4 & 2.6 & 188 \\
\hline & 19R-02 & $66-68$ & 540.86 & 0.75 & 0.077 & 9.8 & 0.56 & -37.3 & 6.94 & 2.24 & 0.92 & 0.46 & 120 & 32 & 2.7 & 1.8 & 140 \\
\hline & 20R-05 & $31-33$ & 554.71 & 0.55 & 0.067 & 8.2 & 1.70 & -25.8 & 5.39 & 3.08 & 0.94 & 0.48 & 240 & 24 & 4.6 & 2.5 & 183 \\
\hline & 22R-02 & $60-62$ & 569.80 & 0.68 & 0.069 & 9.9 & 1.73 & -20.0 & 4.57 & 2.63 & 0.86 & 0.50 & 180 & 31 & 9.4 & 2.6 & 132 \\
\hline & $22 \mathrm{R}-03$ & $90-92$ & 571.04 & 0.54 & 0.063 & 8.5 & 0.96 & -34.8 & 4.86 & 2.41 & 0.89 & 0.51 & 170 & 27 & 2.9 & 1.9 & 59 \\
\hline & 23R-01 & $125-127$ & 578.65 & 0.26 & 0.030 & 8.7 & 2.79 & -0.7 & 8.12 & 5.25 & 1.09 & 0.44 & 90 & 24 & 8.6 & 3.5 & 47 \\
\hline & $23 R-03$ & $101-103$ & 581.41 & 0.52 & 0.058 & 8.9 & 0.76 & -39.2 & 6.88 & 2.90 & 0.95 & 0.36 & 140 & 25 & $1>$ & 1.3 & 197 \\
\hline & 24R-04 & $9-11$ & 590.53 & 0.17 & 0.038 & 4.6 & 6.15 & 11.5 & 7.60 & 5.06 & 0.92 & 0.40 & 60 & 28 & 12.2 & 4.4 & \\
\hline & $25 \mathrm{R}-06$ & $100-102$ & 605.20 & 0.40 & 0.051 & 7.9 & 1.49 & -30.6 & 3.60 & 2.21 & 0.72 & 0.44 & 100 & 26 & $1>$ & 2.3 & 52 \\
\hline & 26R-06 & $114-116$ & 615.04 & 0.51 & 0.069 & 7.4 & 0.83 & -44.4 & 4.49 & 2.17 & 0.76 & 0.35 & 150 & 23 & $1>$ & 6.0 & 52 \\
\hline & $27 \mathrm{R}-02$ & $83-85$ & 618.33 & 0.34 & 0.063 & 5.4 & 2.33 & -21.9 & 6.39 & 4.14 & 0.94 & 0.25 & 230 & 22 & $1>$ & 2.7 & 227 \\
\hline & 28R-02 & $76-78$ & 627.96 & 0.37 & 0.065 & 5.7 & 1.88 & -27.0 & 6.47 & 4.10 & 0.98 & 0.40 & 230 & 22 & 5.3 & 2.5 & 62 \\
\hline & 29R-03 & $63-65$ & 638.93 & 0.40 & 0.052 & 7.8 & 0.48 & -37.7 & 6.50 & 3.12 & 0.95 & 0.32 & 210 & 20 & $1>$ & 2.0 & 164 \\
\hline & $30 \mathrm{R}-03$ & $45-47$ & 648.35 & 0.43 & 0.047 & 9.2 & 1.14 & -39.1 & 5.94 & 2.89 & 0.79 & 0.30 & 190 & 20 & I> & 1.4 & 34 \\
\hline & $31 \mathrm{R}-04$ & $47-49$ & 659.47 & 0.41 & 0.053 & 7.7 & 0.99 & -41.3 & 6.34 & 3.43 & 0.85 & 0.31 & 250 & 19 & $1>$ & 1.6 & 189 \\
\hline & $32 \mathrm{R}-03$ & $13-15$ & 667.33 & 0.70 & 0.059 & 11.8 & 0.61 & -45.3 & 6.67 & 2.67 & 0.85 & 0.38 & 220 & 23 & 8.7 & 1.7 & 74 \\
\hline
\end{tabular}

(diagenetic sulfide deposition) and euxinic bottom water (syngenetic sulfide deposition). TS contents resulting from diagenetic sulfate reduction hardly exceed $2.0 \%$ and are generally less than $1.5 \%$, because the supply of seawater sulfate by diffusion is limited with increasing depth (Goldhaber and Kaplan, 1980; Masuzawa and Kitano, 1983b). A very high TS content indicates syngenetic formation of iron sulfide under an euxinic bottom water.

A method has been proposed to distinguish euxinic $\left(\mathrm{H}_{2} \mathrm{~S}\right.$-containing) from normal marine (dissolved-oxygen-containing) environments by plots of TS vs. TOC of sediments (Leventhal, 1983; Raiswell and Berner, 1985). A TS vs. TOC plot shows a positive correlation with nearly zero TS intercept in normal marine environments, whereas a positive TS intercept between $1 \%$ and $2 \%$ is observed in an euxinic basin (the Black Sea). The positive TS intercept is due to syngenetic formation of iron sulfide under euxinic bottom water.

Figure 7 is a plot of TS vs. TOC of sediments from Site 795 with idealized relationships between TOC and TS in normal marine environments (NM) and in the Black Sea (BS) after Leventhal (1983). The TOC-TS plot for Units $1 \mathrm{~A}$ and $1 \mathrm{~B}$ (Fig. 7A) is quite different from those for Units 2 to 5 (Figs. 7B-7D). Both TOC and TS contents are highly variable in Units $1 \mathrm{~A}$ and $1 \mathrm{~B}$ with many layers of very low TOC and TS contents (Fig. 7A).

In Units $1 \mathrm{~A}$ and $1 \mathrm{~B}$ many of the TS contents are much higher than the idealized relationship for normal marine sediments (NM) and higher 
Table 1 (continued).

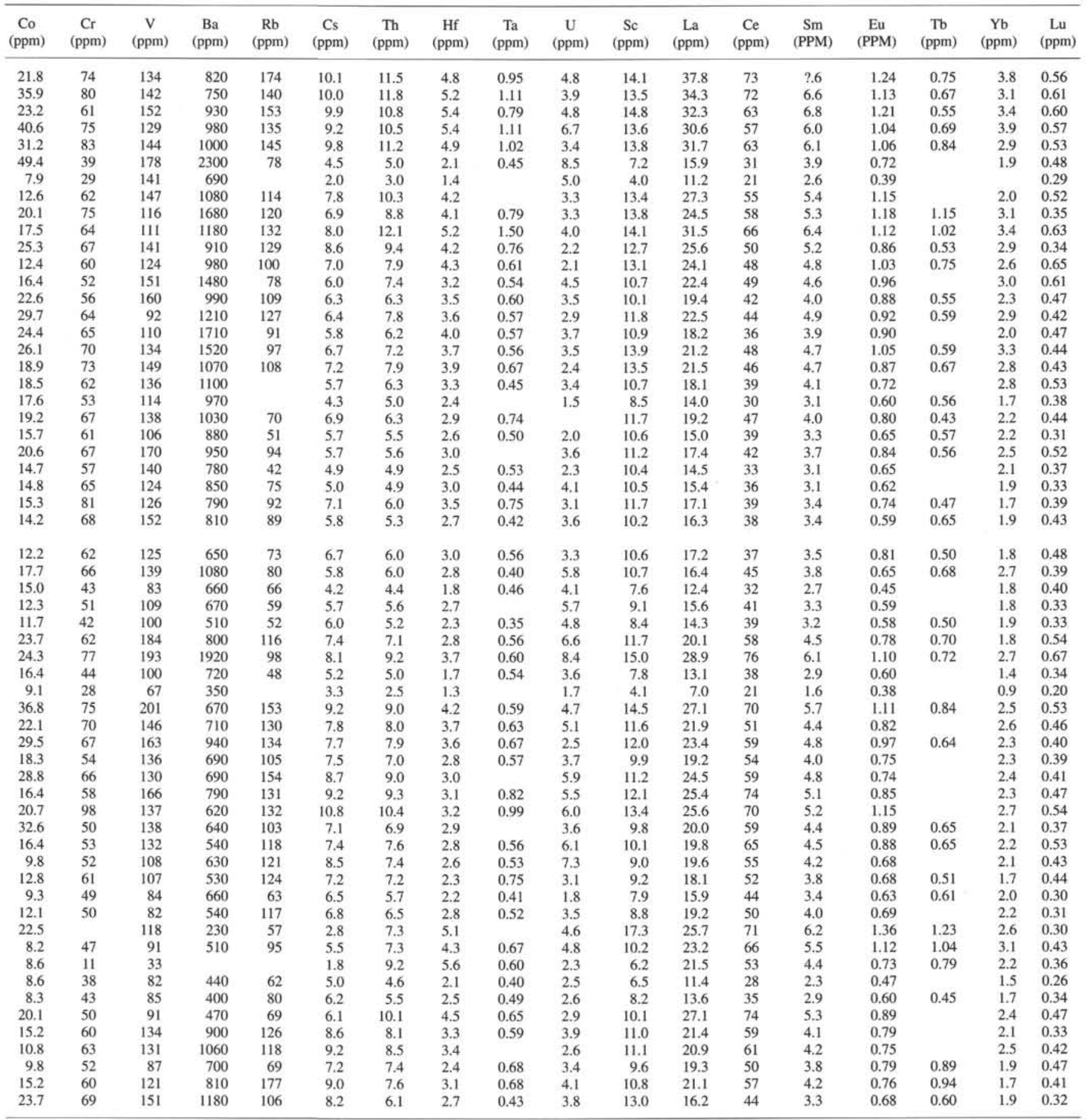

than that for Black Sea sediments (BS). This suggests a drastic variation between oxic (low TOC and low TS contents) and euxinic (high TOC and very high TS contents) bottom waters in these sequences.

On the other hand, TOC $(0.15 \%-0.96 \%)$ and TS $(0.15 \%-1.42 \%)$ contents in Unit 2 are low and show a positive correlation except for a sample ( $\mathrm{TS}=4.24 \%$ ) (Fig. 7B). This suggests diagenetic sulfate reduction under oxic bottom waters in Unit 2. In Unit 3 (Fig. 7C), there are samples showing a positive correlation between TOC and TS with TS contents of $<1.6 \%$ and samples with moderate TS contents (ca. 2\%). The former suggests diagenetic sulfate reduction, and the latter euxinic bottom waters.
The TOC and TS plot in Units 4A, 4B, and 5 (Fig. 7D) may be divided into three groups: low TOC and TS $(<1.4 \%)$ contents showing a positive correlation between them, moderate TS contents of $1.4 \%-$ $2.4 \%$, and very high TS contents $(>2.5 \%)$ with a very low TOC content $(<0.5 \%)$. The former two suggest diagenetic sulfate reduction and euxinic bottom waters, respectively, similarly to those in Unit 3. Several samples with very high TS and very low TOC $(<0.6 \%)$ contents in Unit 2 (Fig. 7B) and Units 4A, 4B, and 5 (Fig. 7D) suggest different mechanisms of sulfur accumulation with no support of TOC. Some of these layers are those that contain angular pyrite grains with a very high $\delta^{34} \mathrm{~S}_{\mathrm{CDT}}$ value and will be discussed later. 


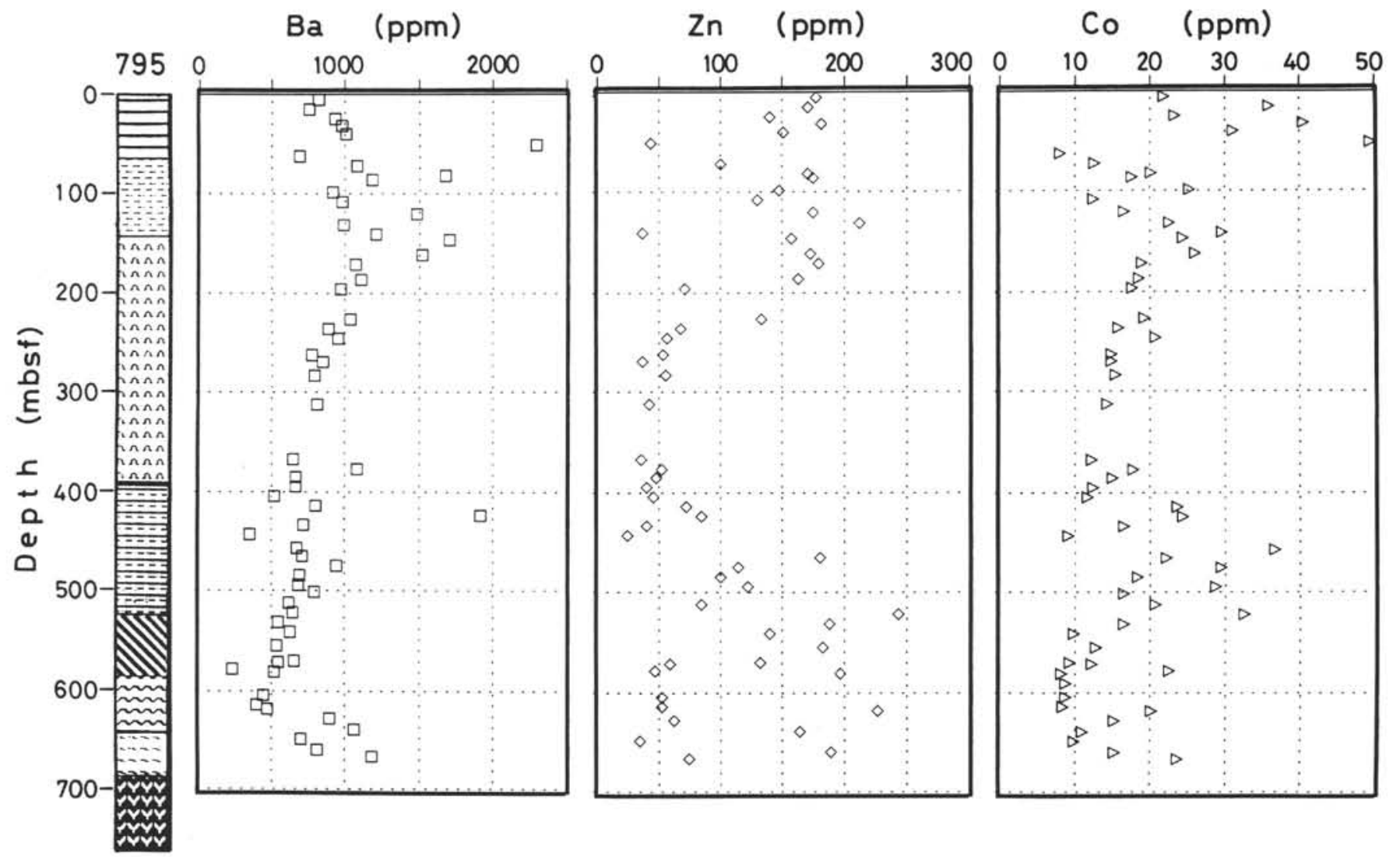

Figure 4. Vertical profiles of $\mathrm{Ba}$ (left), $\mathrm{Zn}$ (middle), and Co (right) at Site 795 (lithology as in Fig. 1).

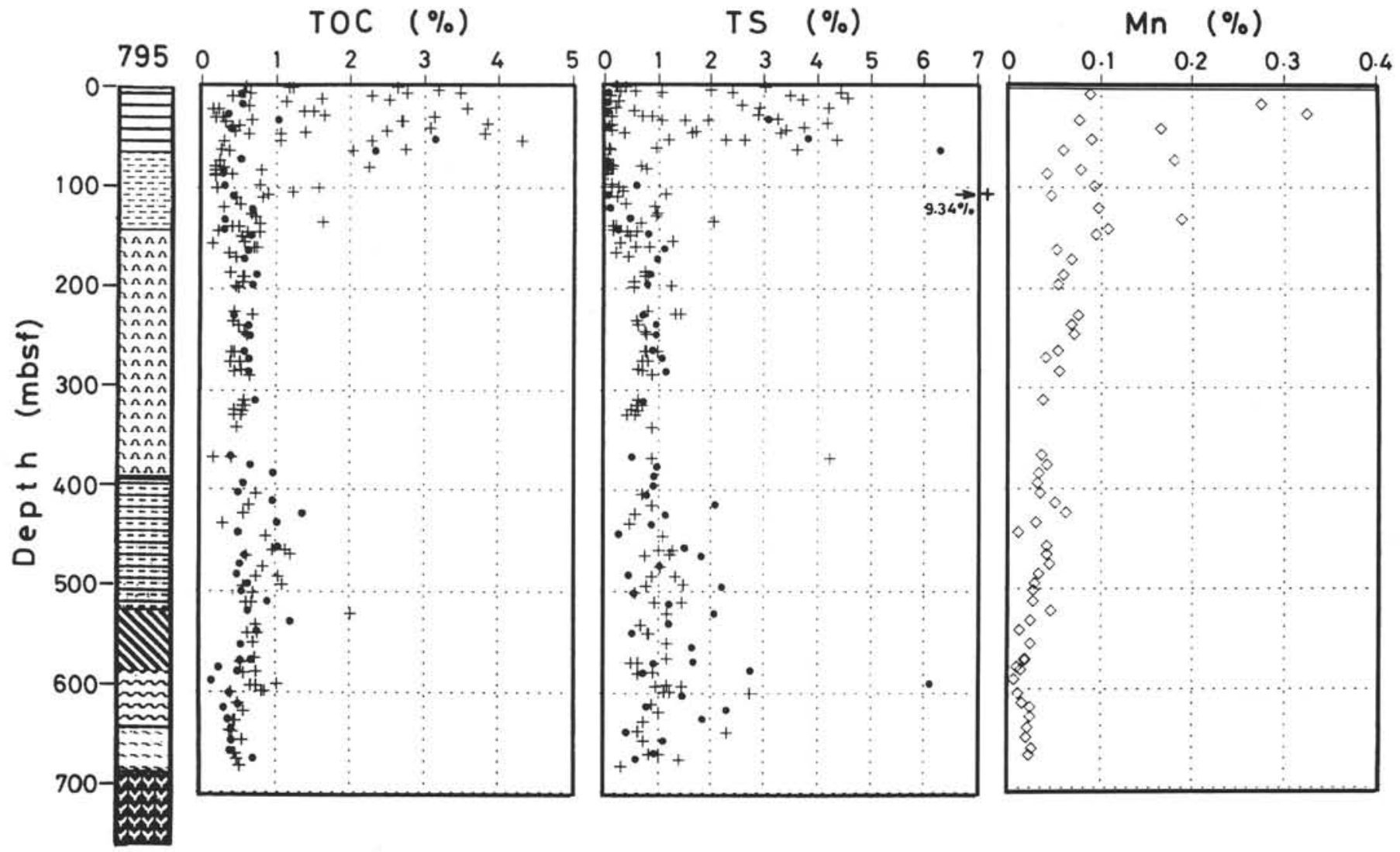

Figure 5. Vertical profiles of total organic carbon (TOC; left), total sulfur (TS; middle), and Mn (right) at Site 795 (lithology as in Fig. 1). Crosses for TOC and TS are from shipboard results (Tamaki, Pisciotto, Allan, et al., 1990). 

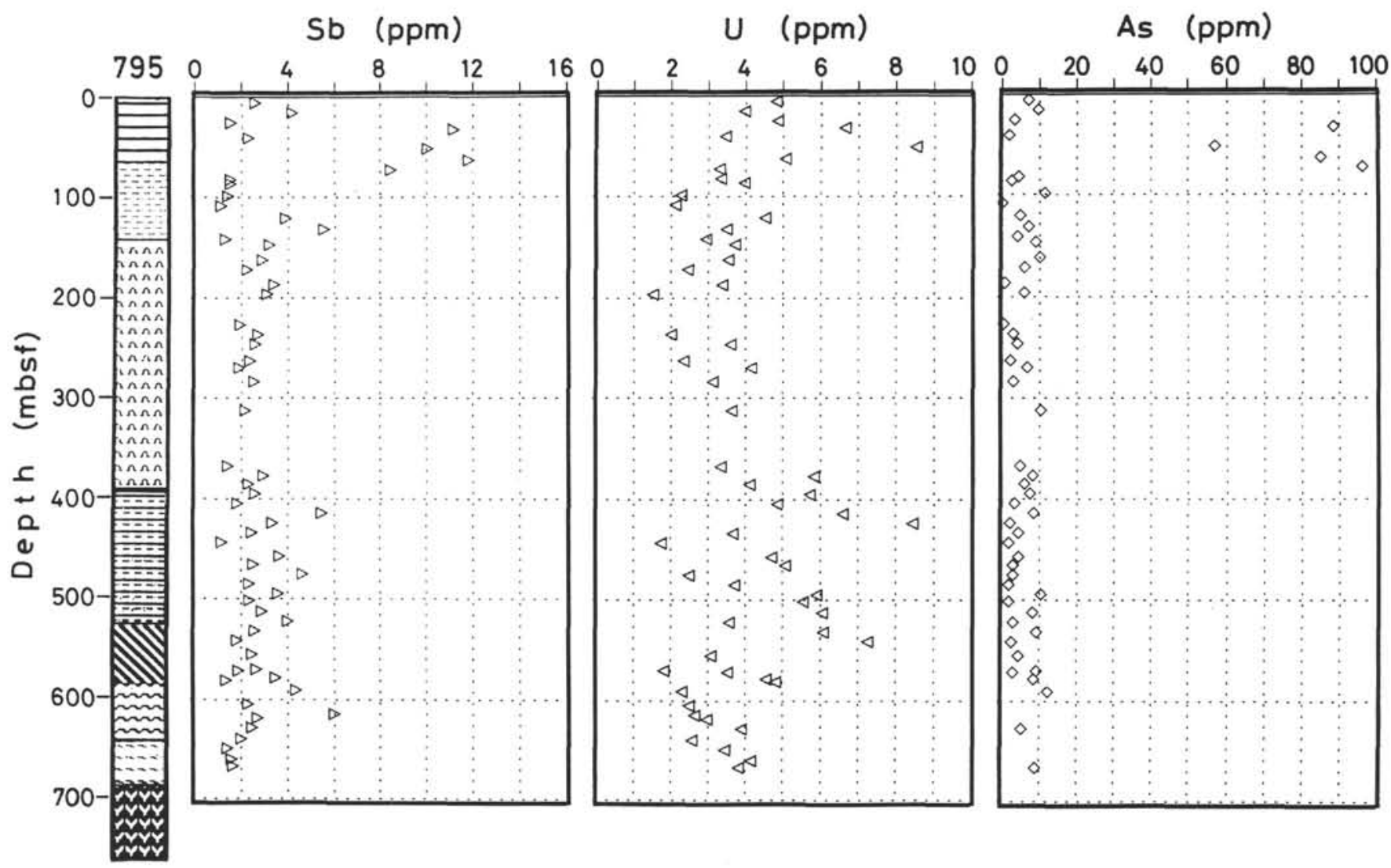

Figure 6. Vertical profiles of Sb (left), U (middle) and As (right) at Site 795 (lithology as in Fig. 1).

\section{$\mathrm{Mn}, \mathrm{Sb}, \mathrm{U}$, and As}

Mn content is highly variable in Units $1 \mathrm{~A}$ and $1 \mathrm{~B}$ but decreases with increasing depth below Units $1 \mathrm{~A}$ and $1 \mathrm{~B}$ (Fig. 5). Sb content also varies remarkably in Units $1 \mathrm{~A}$ and $1 \mathrm{~B}$, and shows a moderate value in Unit 2 and a slightly higher value in Units 3, 4A, 4B, and 5 (Fig. 6). $\mathrm{U}$ content shows a high variation in Units $1 \mathrm{~A}, 1 \mathrm{~B}, 3,4 \mathrm{~A}, 4 \mathrm{~B}$, and 5 , and a relatively low value in Unit 2 (Fig. 6). As content varies significantly in Units $1 \mathrm{~A}$ and $1 \mathrm{~B}$ and is low in Units 2 to 5 (Fig. 6). Then TOC, TS, Mn, Sb, U, and As contents vary from very low to very high values in Units $1 \mathrm{~A}$ and $1 \mathrm{~B}$.

Masuzawa et al. (in press) distinguished different redox conditions in Core KH77-3-L4' from vertical profiles of Mn, Sb, U, As, TS, and TOC: (1) oxic with high $\mathrm{Mn}(>0.3 \%)$ as $\mathrm{Mn}$ (IV) oxide or $\mathrm{Mn}$ (II) carbonate occasionally with positive $\mathrm{Ce}$ anomaly and low TS $(<0.1 \%)$; (2) suboxic with high $\mathrm{Sb}(>2 \mathrm{ppm})$, high $\mathrm{U}(>3 \mathrm{ppm})$, and low TS $(<0.1 \%)$; and ( 3$)$ euxinic with quite high TS $(>1 \%)$ and As $(>25 \mathrm{ppm})$ and low $\mathrm{Mn}(<0.15 \%)$.

$\mathrm{Mn}$ (II) is soluble under reducing conditions but precipitates as Mn(IV) oxides in oxic environments. Thus a high accumulation of Mn as $\mathrm{Mn}$ (IV) oxide or $\mathrm{Mn}$ (II) carbonate, which can be formed through diagenetic transformation from Mn(IV) oxide (Masuzawa et al., in press), indicates an environment containing dissolved oxygen.

$\mathrm{Sb}(\mathrm{V})$ and $\mathrm{U}(\mathrm{VI})$ are soluble under oxic conditions but become insoluble by reduction to $\mathrm{Sb}(\mathrm{III})$ and $\mathrm{U}(\mathrm{IV})$ under reducing conditions. As(V) is soluble under oxic conditions but forms an insoluble sulfide in the presence of hydrogen sulfide. A high accumulation of TS concurrent with a very high As content also indicates an euxinic condition, and high $\mathrm{Sb}$ and $\mathrm{U}$ concurrent with low TS, a suboxic (no dissolved oxygen and no $\mathrm{H}_{2} \mathrm{~S}$ ) environment. This is due to the fact that the equilibrium pe (negative logarithm of electron activity) values of $\mathrm{Sb}(\mathrm{V}) / \mathrm{Sb}(\mathrm{III}), \mathrm{U}(\mathrm{VI}) / \mathrm{U}(\mathrm{IV})$, and $\mathrm{As}(\mathrm{V}) / \mathrm{As}(\mathrm{III})$ couples decrease in this order and lie between those of $\mathrm{Mn}(\mathrm{IV}) / \mathrm{Mn}(\mathrm{II})$ and $\mathrm{S}(\mathrm{VI}) / \mathrm{S}(-\mathrm{II})$ in seawater at $\mathrm{pH} 8.2$ (Turner et al., 1981).

Figures 8 and 9 show the high-resolution vertical profiles of TOC, TS, Mn, Sb, U, and As in Units $1 \mathrm{~A}$ and $1 \mathrm{~B}$ at Site 795. The shipboard results of TOC and TS (Tamaki, Pisciotto, Allan, et al., 1990) are included in Figure 8. As seen from this figure, TOC and TS contents tend to vary in very much the same way. Low-Mn layers almost coincide with layers showing maximum TOC and TS contents and high-Mn layers, with layers showing minimum TOC and TS contents (Fig. 8). Layers showing high Sb, U, and As contents usually coincide with layers showing high TOC and TS contents; low Sb, U, and As contents coincide with layers having low TOC and TS contents (Fig. 9).

\section{Sulfur Isotope Ratio of Sedimentary Pyrite}

Sedimentary pyrite was isolated from sediment samples with a high TS content (ca. $>0.5 \%$ ). Most sedimentary pyrite grains isolated from sediment samples at Site 795 are framboidal pyrite spherules (Pl. 1.2) with a diameter of 5-30 $\mu \mathrm{m}(\mathrm{Pl} .1 .1)$ and almost pure $\mathrm{FeS}_{2}$ composition according to EDS analysis (Pl. 1.3).

The sulfur isotope ratio can give significant information about the sulfur source. Basaltic sulfur has a $\delta^{34} \mathrm{~S}_{\mathrm{CDT}}$ value close to $0 \%$, hydrothermal fluids a positive value ranging from $+1 \%$ oo to $+10 \%$, and present-day seawater sulfate-S has a value of $+20 \%$. A rather low value for the sulfur isotope ratio of hydrogen sulfide results from microbial sulfate reduction (e.g., Chambers and Trudinger, 1979; Ohmoto et al., 1990).

The $\delta^{34} \mathrm{~S}_{\mathrm{CDT}}$ value of hydrogen sulfide formed through diagenetic sulfate reduction becomes higher as diagenetic sulfate reduction proceeds, because the $\delta^{34} \mathrm{~S}_{\mathrm{CDT}}$ value of residual sulfate becomes higher due to the limited supply of sulfate from seawater. Therefore framboidal pyrite spherules formed diagenetically possess a higher $\delta^{34} \mathrm{~S}_{\mathrm{CDT}}$ value (Goldhaber and Kaplan, 1974, 1980). On the other 

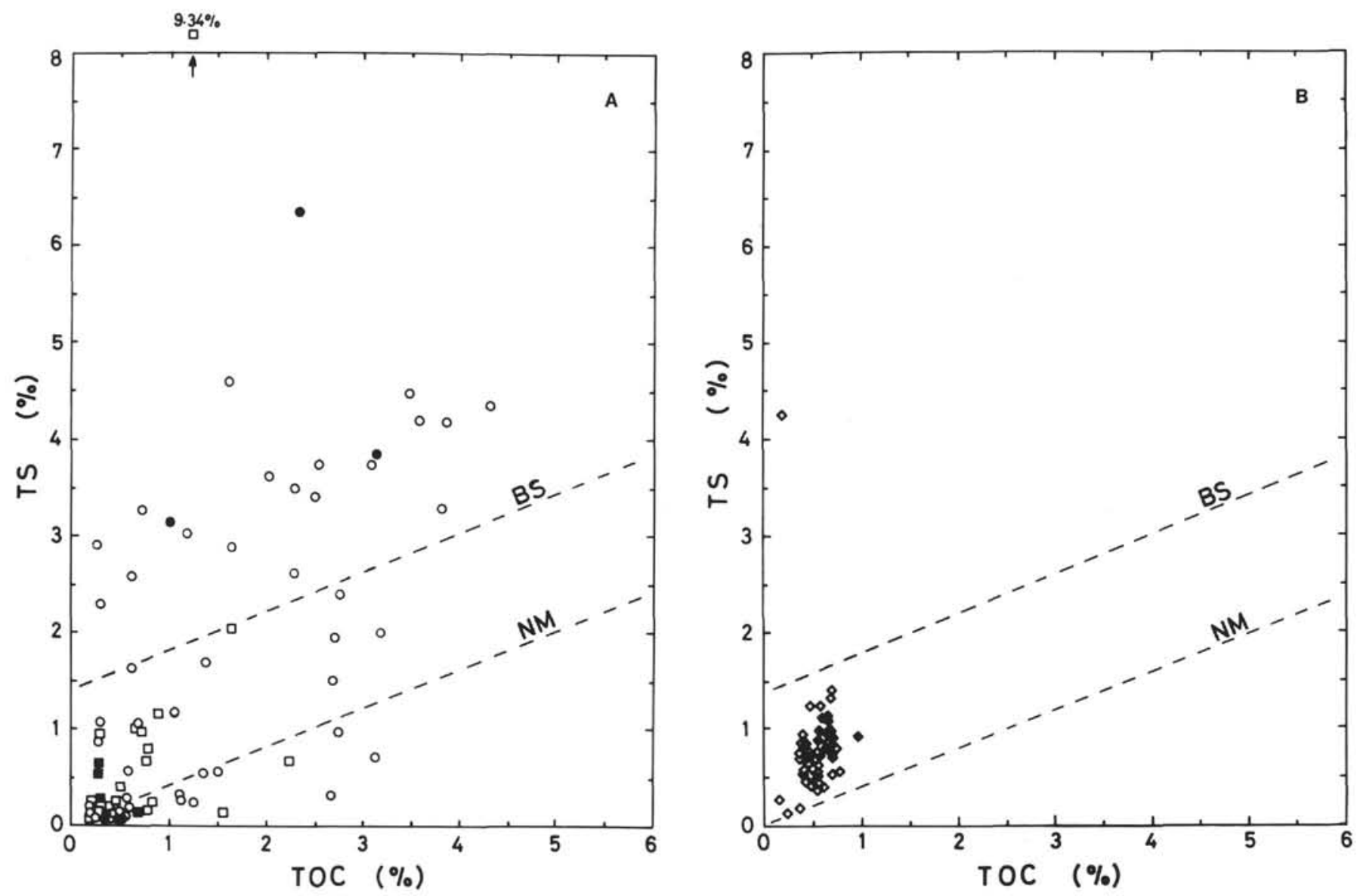

Figure 7. Plots of TS vs. TOC of sediments from Site 795. A. Units $1 \mathrm{~A}(\bullet, \circ)$ and $1 \mathrm{~B}(\boldsymbol{\bullet}, \square)$. B. Unit $2(\bullet, \diamond)$. C. Unit $3(\triangleleft, \triangleleft)$. D. Units $4 \mathrm{~A}(\boldsymbol{\Delta}$, $\triangle), 4 \mathrm{~B}(\boldsymbol{\nabla}, \nabla)$ and $5(\triangleright, \triangleright)$ ). Open marks are those from shipboard results (Tamaki, Pisciotto, Allan, et al., 1990). Broken lines show idealized relationships for normal marine (NM) and Black Sea (BS) sediments after Leventhal (1983).

hand, the $\delta^{34} \mathrm{~S}_{\mathrm{CDT}}$ value of sulfate in euxinic bottom waters maintains the seawater sulfate value, and $\delta^{34} \mathrm{~S}_{\mathrm{CDT}}$ value of microbially formed hydrogen sulfide is very low, because the supply of seawater sulfate is not limited as observed in the Black Sea where it reaches values as low as $-38.7 \%$ oo to $-40.9 \%$ (Sweeney and Kaplan, 1980). Framboidal pyrite spherules formed under euxinic bottom waters have a quite low $\delta^{34} \mathrm{~S}_{\mathrm{CDT}}$ value. This is consistent with observation of Masuzawa and Kusakabe (unpubl. data), who reported that framboidal pyrite spherules in Core KH77-3-LAé formed under euxinic bottom waters during the last glacial period have very low $\delta^{34} \mathrm{~S}_{\mathrm{CDT}}$ values of $-50 \%$ o to $-35 \%$, whereas diagenetically formed framboidal pyrite spherules in a piston core from the central Japan Basin (KH77-3-M5) show higher values ranging from $-25 \%$ oo to $-10 \%$.

Figure 10 illustrates the vertical profile of $\delta^{34} \mathrm{~S}_{\mathrm{CDT}}$ values of isolated sedimentary pyrite at Site 795 . These values range from $-48.3 \%$ o to $+14.2 \%$. Figure 11 shows the relationship between TS content of sediments and $\delta^{34} \mathrm{~S}_{\mathrm{CDT}}$ value of pyrite in the seven lithologic units of Site 795. TS content is quite high $(>2 \%)$ and $\delta^{34} \mathrm{~S}_{\mathrm{CDT}}$ is quite low $(<-35$ $\circ \%$ ) in Unit 1A, indicating syngenetic formation of pyrite under euxinic bottom waters (syngenetic zone in Fig. 11). This was also reported in samples from Core $\mathrm{KH} 77-3-\mathrm{L}^{\prime}$ corresponding to the last glacial period in the Japan Sea (Masuzawa and Kusakabe, unpubl. data). $\delta^{34} \mathrm{~S}_{\mathrm{CDT}}$ is also very low, with relatively low TS content $(<1 \%)$ in Unit $1 B$. In Unit 2 the $\delta^{34} \mathrm{~S}_{\mathrm{CDT}}$ value increases significantly up to $+1.6 \%$, concurrent with a gradual increase in TS content, which is less than $1.2 \%$. This trend and the TOC-TS correlation (Fig. 7B) are consistent with diagenetic formation of pyrite through diagenetic sulfate reduction (diagenetic zone in Fig. 11 ), where TS content has an upper limit due to the limited supply of seawater sulfate through diffusion in pore water (Goldhaber and Kaplan, 1980; Masuzawa and Kitano, 1983b). Unit 3 values are distributed in both syngenetic and diagenetic zones. Many values of Units $4 \mathrm{~A}$ and $4 \mathrm{~B}$ and also some of Unit 3 are plotted in a region existing between syngenetic and diagenetic zones. This may suggest diagenetic as well as syngenetic formation of framboidal pyrite (syngenetic + diagenetic zone in Fig. 11).

Crosses in Figure 11 illustrate data from pelagic surface sediments from the Black Sea after Vinogradov et al. (1962). $\delta^{34} \mathrm{~S}_{\mathrm{CDT}}$ values of these pyrite samples range from $-26 \%$ to $-34 \%$ (Vinogradov et al., 1962) and are higher than those of hydrogen sulfide in the overlying bottom water of the Black Sea (-38 \% \%o to $-41 \%$ o ); Sweeney and Kaplan, 1980). These crosses are found in the syngenetic + diagenetic zone near the diagenetic zone in Figure 11. Active sulfate reduction takes place within the surface sediment layer of the Black Sea, and pore-water sulfate shows a higher $\delta^{34} \mathrm{~S}_{\mathrm{CDT}}$ value than that of the overlying bottom water (Vinogradov et al., 1962). Therefore pyrite-S in the Black Sea surface sediments is likely to be formed from both hydrogen sulfide in the overlying bottom water (syngenetic) and through diagenetic sulfate reduction within the surface sediments. The fact that the samples from Black Sea sediments (crosses) lie in the syngenetic + diagenetic zone supports the zoning in Figure 11 described for Site 795.

Three samples from $464.96,578.65$, and $590.53 \mathrm{mbsf}$ show the very high $\delta^{34} \mathrm{~S}_{\mathrm{CDT}}$ values of $+14.2 \% \%$, $-0.7 \%$, and $+11.5 \%$, respectively, which are similar to those of hydrothermal sulfides; TS contents of these samples are also very high. Pyrite grains isolated from these sediments are mainly composed of large angular grains with a diameter of 30-60 $\mathrm{mm}$ (Pl. 1.4) without framboidal texture (PI. 1.5) and show almost pure 


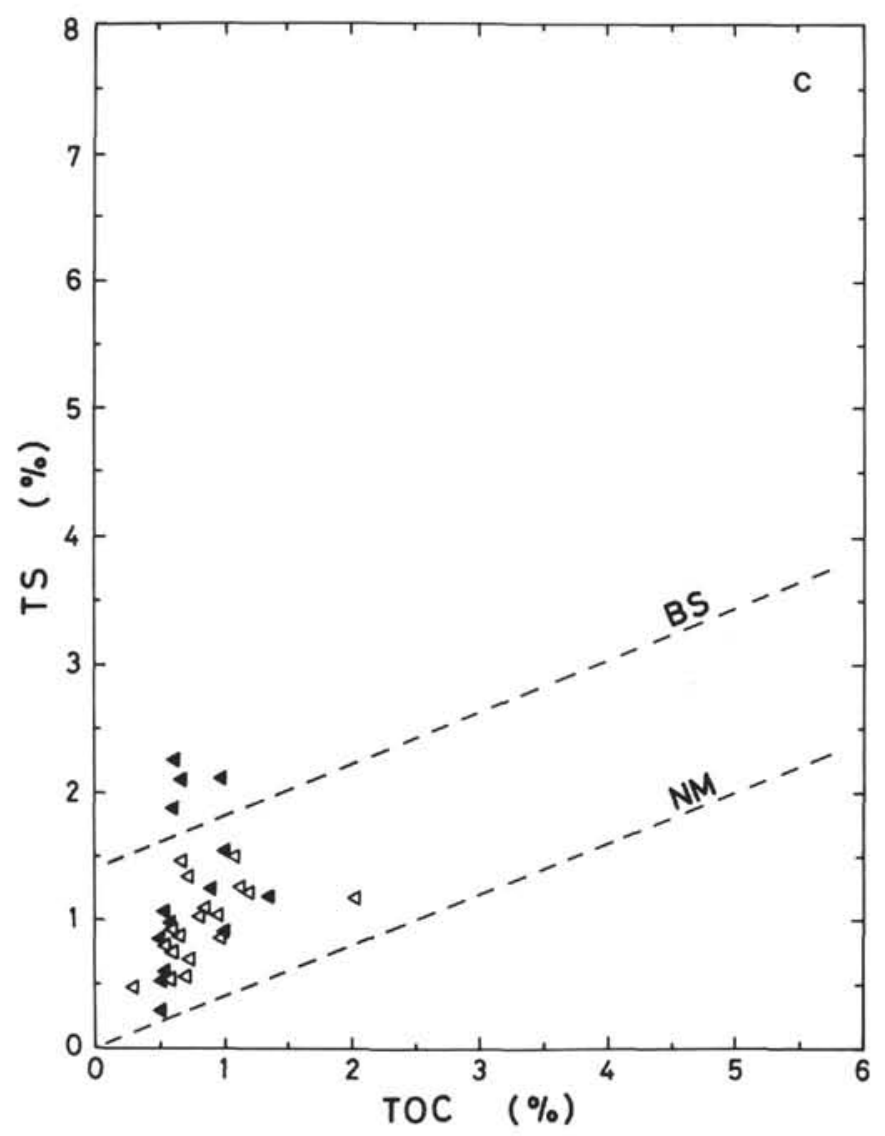

Figure 7 (continued).

$\mathrm{FeS}_{2}$ composition (Pl. 1.6). The TOC contents of these layers are very low $(<0.6 \%$; Fig. 7$)$. These facts suggest an origin for these pyrite grains different from syngenetic or diagenetic microbial sulfate reduction. One possibility is an origin associated with hydrothermal activity, and thus the zone is called hydrothermal(?) in Figure 11.

\section{Change in Redox Condition of Japan Sea Bottom Water}

The variation in redox condition of the Japan Sea bottom water since its birth (13.0-15.0 Ma) can be estimated from the vertical profiles of TOC, TS, Mn (Figs. 5 and 8), Sb, U, As (Figs. 6 and 9), and $\delta^{34} \mathrm{~S}_{\mathrm{CDT}}$ of sedimentary pyrite (Fig. 10), TOC-TS plots (Fig. 7), and TS- $\delta^{34} S_{\mathrm{CDT}}$ relationships (Fig. 11) by reference to data from Core KH77-3-L4' (Masuzawa and Kitano, 1984; Masuzawa and Kusakabe, unpubl. data; Masuzawa et al., in press).

In Units $1 \mathrm{~A}$ and $1 \mathrm{~B}(0-2.4 \mathrm{Ma})$, layers with low TOC $(<0.7 \%)$ and very low TS $(<0.3 \%)$ contents, where Mn content is high $(>0.15 \%)$ and $\mathrm{Sb}, \mathrm{U}$, and $\mathrm{As}$ are low $(<6,<5$, and $<15 \mathrm{ppm}$, respectively), are thought to have been deposited as oxidized sediments under oxic conditions similar to the present Japan Sea. Layers with quite high TOC $(>2 \%)$ and TS $(>2 \%)$ contents, where Mn content is low $(<0.1 \%), \mathrm{Sb}$ and $\mathrm{U}$ contents are high ( $>6$ and $>5 \mathrm{ppm}$, respectively), and As content is very high ( $>25 \mathrm{ppm}$ ), are considered to have been deposited under euxinic conditions similar to those thought to have been prevalent during the last glacial period in the Japan Sea. This is indicated by the very low $\delta^{34} \mathrm{~S}_{\mathrm{CDT}}$ values of framboidal pyrite spherules isolated from these high TS layers (Fig. 11). The oxic-euxinic variation is remarkable in Unit $1 \mathrm{~A}$, where at least 11 cycles of oxic-euxinic variation are observed during the last 1.2 Ma (Fig. 8).

In Unit 2 (ca. 2.4 to 6-7 Ma), which is composed of diatom ooze and diatom clay, Mn content is low, TOC and TS contents are

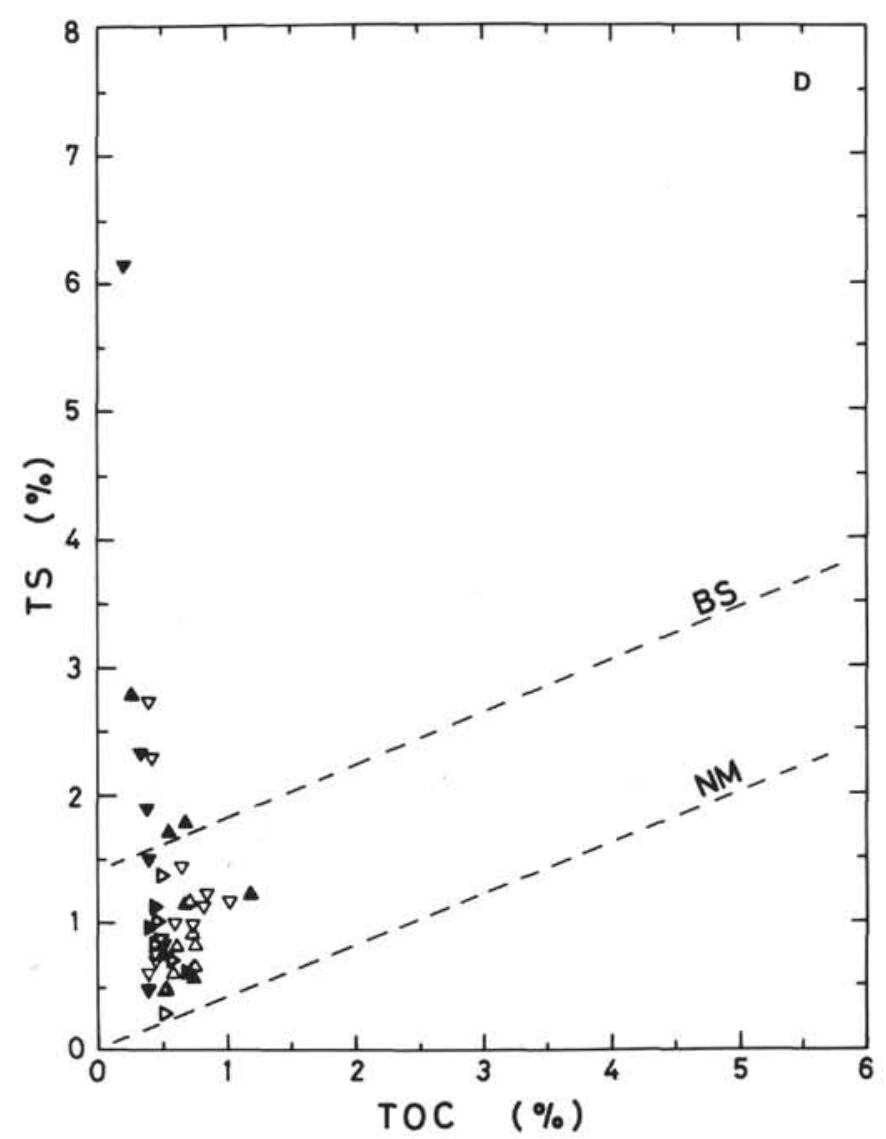

relatively low $(0.15 \%-0.19 \%$ and $0.15 \%-1.42 \%$, respectively) with a positive correlation (Fig. 7B), and $\mathrm{Sb}, \mathrm{U}$, and As contents are relatively high (Fig. 6). As discussed earlier, $\delta^{34} S_{\mathrm{CDT}}$ value of sedimentary pyrite increases significantly with a gradual increase in TS content, indicating diagenetic formation of pyrite spherules through diagenetic sulfate reduction under oxic bottom water. These facts suggest an active diagenetic sulfate reduction beneath oxic bottom water, probably without any thick surface oxidized layer. In the present Japan Sea, surface oxidized layers appear below ca. $2000 \mathrm{~m}$, whereas active diagenetic sulfate reduction in sediments without a surface oxidized layer occurs above ca. $2000 \mathrm{~m}$, sulfate reduction beneath a thin surface oxidized layer has been reported between ca. 2000 and $3000 \mathrm{~m}$ of water (Masuzawa, 1987). The bottom water during the period represented in Unit 2 seems to be steadily oxic but the sedimentary condition was less oxic than the present Japan Sea. This condition is probably due to a greater supply of organic matter through very high productivity as indicated by the very high diatom content in Unit 2 sediments.

The lithology of Unit 3 shows rhythmical alternations of dark and light diatom silty clay or siliceous silty claystone (Tada and Iijima, this volume). TOC and TS contents suggest two types of sediment layers: one dominated by diagenetic sulfate reduction (TS $<1.6 \%)$ and the other resulting from deposition under euxinic bottom water (TS $=\mathrm{ca} .2 \%$; Fig. $7 \mathrm{C}$ ). $\mathrm{Sb}$ and $\mathrm{U}$ contents are relatively high, and $\mathrm{Mn}$ and As contents are low (Figs. 5 and 6 ). The $\delta^{34} \mathrm{~S}_{\mathrm{CDT}}$ values lie in the diagenetic, syngenetic + diagenetic, and syngenetic zones in Figure 11. These facts suggest a variation between less oxic and less euxinic conditions in Unit 3.

Unit $4 \mathrm{~A}$ is composed of rhythmical alternations of dark chert and light siliceous claystone, and Unit $4 \mathrm{~B}$ is characterized by siliceous claystone with horizontal burrows (Tada and lijima, this volume). The 


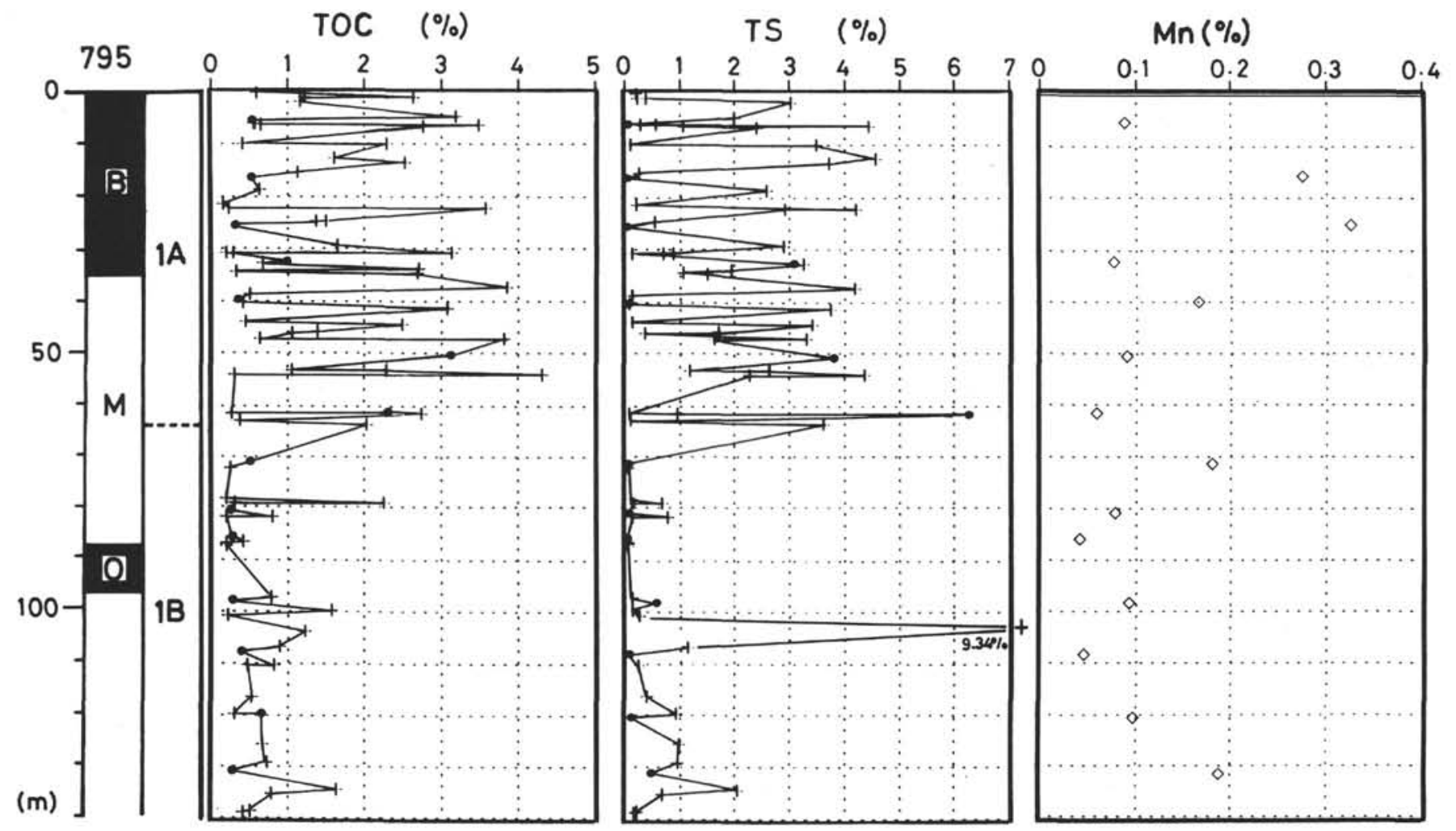

Figure 8. High-resolution vertical profiles of TOC (left), TS (middle), and Mn (right) in the upper 140-m layer at Site 795. Crosses for TOC and TS are from shipboard results (Tamaki, Pisciotto, Allan, et al., 1990). The left-side column shows the magnetic polarity of Brunhes Normal Epoch (B), Matsuyama Reversed Epoch (M), and Olduvai Event (O) (Tamaki, Pisciotto, Allan, et al., 1990), and the lithologic units (Units 1A and 1B; Tada and lijima, this volume).

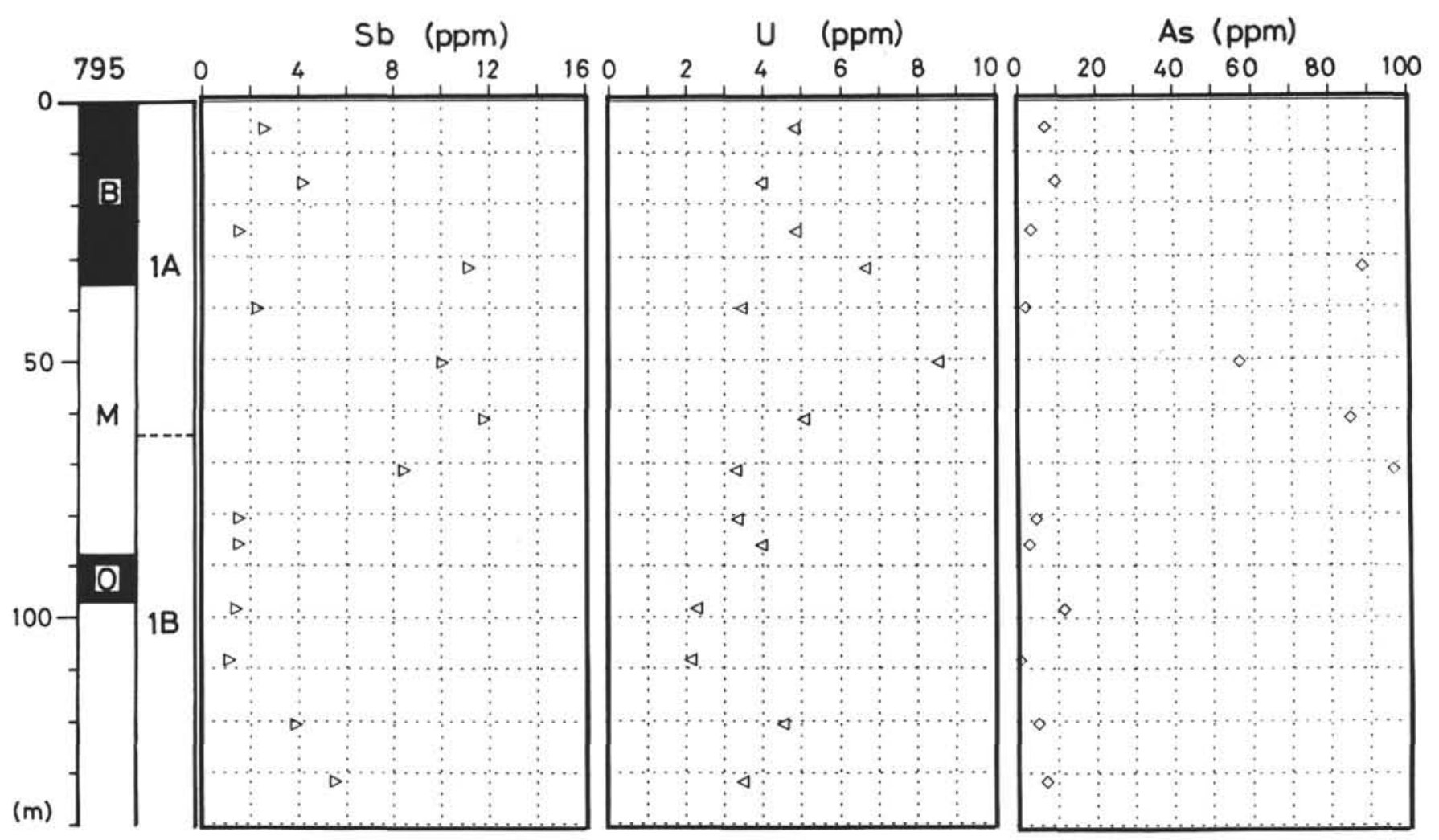

Figure 9. High-resolution vertical profiles of Sb (left), U (middle), and As (right) in the upper 140-m layer at Site 795 (magnetic polarity and lithology as in Fig. 8). 


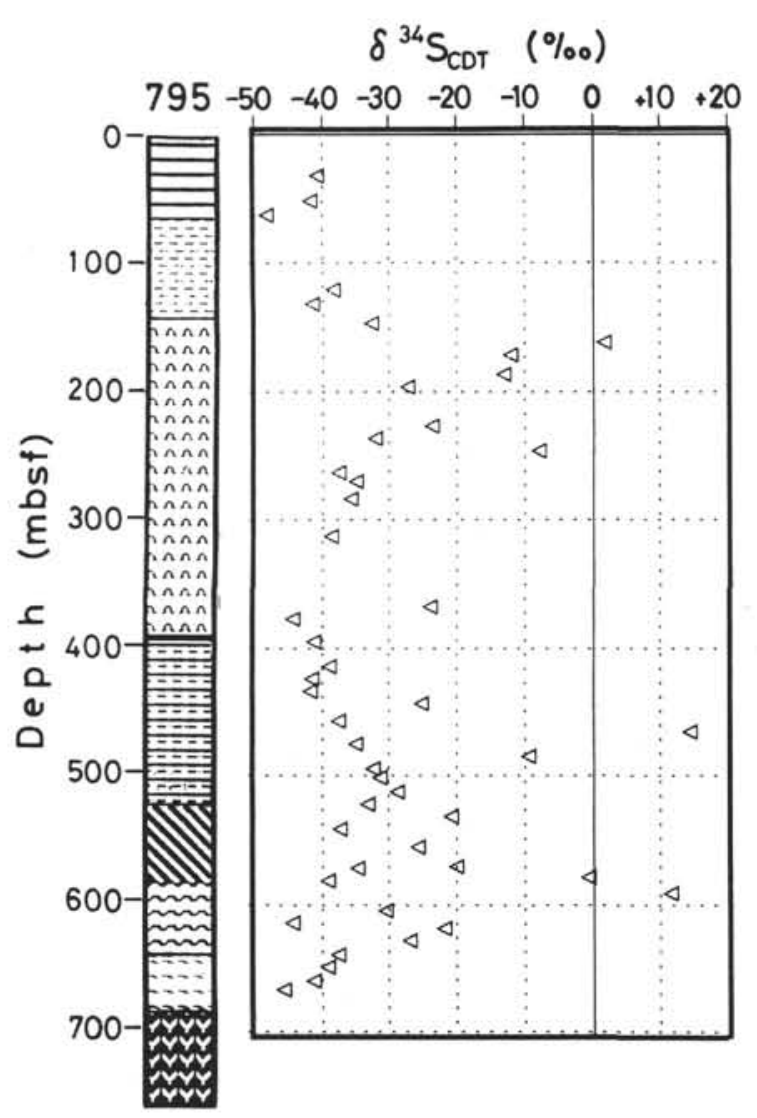

Figure 10. Vertical profile of $\delta^{34} \mathrm{~S}_{\mathrm{CDT}}$ of sedimentary pyrite isolated from sediments at Site 795 (lithology as in Fig. 1).

variations of TOC, TS, Mn, Sb, U, and As contents in Units 4A and $4 \mathrm{~B}$ are similar to those in Unit 3 except for a few layers with very high TS $(>2.5 \%)$ and very low TOC $(<0.5 \%)$ contents (Figs. 5,6 , and 7$)$. Layers showing very high TOC, TS, and As contents and with low Mn content, or layers having very low TOC, TS, and As contents and with high Mn content were not observed among the samples analyzed here. Many $\delta^{34} \mathrm{~S}_{\mathrm{CDT}}$ values of pyrite in Units $4 \mathrm{~A}$ and $4 \mathrm{~B}$ are distributed in the syngenetic + diagenetic zone in Figure 11 with relatively low TS content. These facts suggest that redox conditions in Units $4 \mathrm{~A}$ and 4B were similar to those in Unit 3, i.e., a variation between less oxic and less euxinic conditions.

Unit 5 is described as claystone with faint laminations and horizontal burrows (Tada and Iljima, this volume). The variations of TOC, $\mathrm{TS}, \mathrm{Mn}, \mathrm{Sb}, \mathrm{U}$, and As contents and that of $\delta^{34} \mathrm{~S}_{\mathrm{CDT}}$ value of pyrite are also similar to those in Units 3,4A, and 4B (Figs. 5, 6, 7, 10, and 11). These facts also suggest that the redox conditions in Unit 5 were similar to those of Units 3,4A, and 4B.

Layers of relatively high TS and very low TOC contents were found in Units 2, 3, 4A, and 4B. Some of them contain large, angular pyrite grains without framboidal texture and a very high $\delta^{34} \mathrm{~S}_{\mathrm{CDT}}$ value. These facts may suggest a hydrothermal origin. More detailed studies, however, will be needed to confirm possible hydrothermal activity in these layers.

\section{SUMMARY}

The changes in the redox conditions of the bottom water in the Japan Sea since its birth were estimated from vertical variations of redox-sensitive elements (TOC, TS, $\mathrm{Mn}, \mathrm{Sb}, \mathrm{U}$, and $\mathrm{As}$ ) and the sulfur isotope ratio of isolated sedimentary pyrite of 60 sediment samples

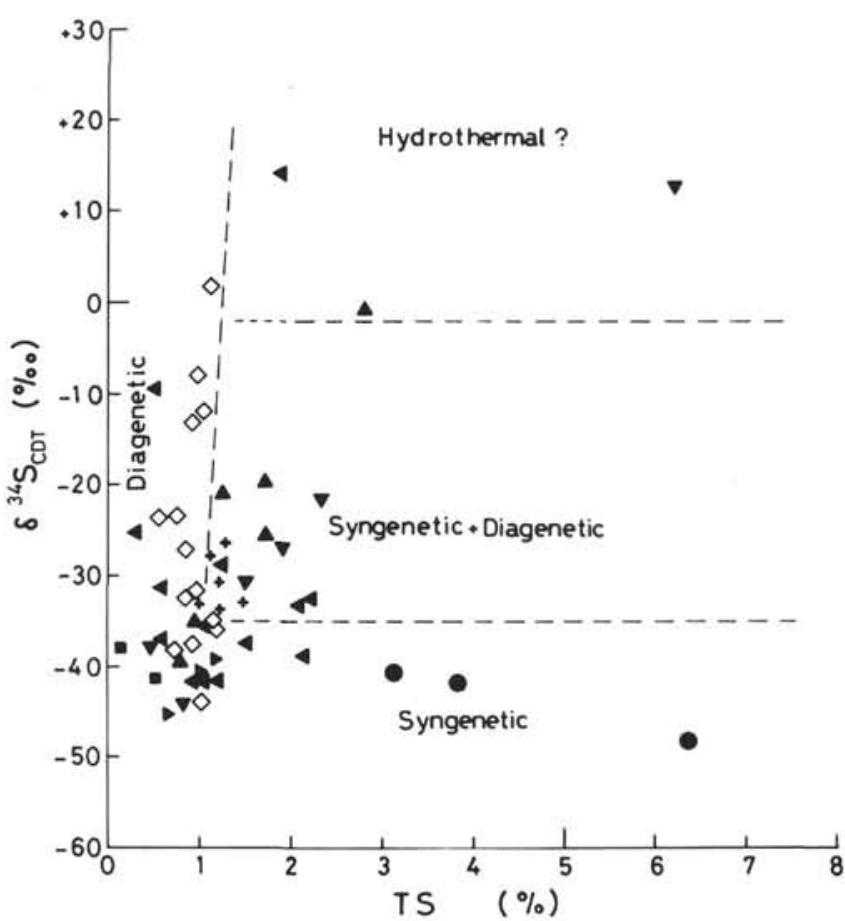

Figure 11. Relationship between TS of sediments and $\delta^{34} \mathrm{~S}_{\mathrm{CDT}}$ of sedimentary pyrite in seven lithologic units at Site 795: Units 1A ( $\bullet$ ) and 1B ( $\mathbf{m})$, Unit $2(\diamond)$, Unit $3(\triangleleft)$, Units $4 \mathrm{~A}(\Delta)$ and $4 \mathrm{~B}(\boldsymbol{\nabla})$, and Unit $5(\diamond)$ ). Crosses are data from pelagic surface sediments of the Black Sea (Vinogradov et al., 1962).

collected every $10 \mathrm{~m}$ from Site 795 . The estimated changes in the redox conditions of the Japan Sea bottom water are as follows: a variation between less oxic and less euxinic in Units 5, 4B, 4A, and 3 (ca. 13-15 to 6-7 Ma); oxic but less so than that of the present Japan Sea with diagenetic sulfate reduction under high biological productivity in Unit 2 (ca. 7-6 to 2.4 Ma); and a drastic variation between oxic, similar to the present Japan Sea bottom water, and euxinic, similar to that during the last glacial period, in Units 1B (ca. 2.4-1.2 $\mathrm{Ma}$ ) and $1 \mathrm{~A}$ (ca. 1.2 Ma to the present), especially in Unit 1A. The gradual increase in Mn content with time suggests the accumulation of manganese in deep-sea sediments of the Japan Sea throughout its geologic history.

The results reported here are thought to represent a general picture of the environmental changes taking place in the Japan Sea since its birth, although the results are based on only 60 sediment samples collected every $10 \mathrm{~m}$. The environmental changes of the sea have been very rapid and drastic as observed in Units 1A and 1B (e.g., Fig. 8) and in Core KH77-3-L4'. Further studies on high-resolution samples from Site 795 are needed to determine in more detail the environmental changes throughout the geologic history of the Japan Sea.

\section{ACKNOWLEDGMENTS}

We thank H. Chiba and T. Nogi of Okayama University for their assistance with the sulfur isotope measurement. We are indebted to Prof. Y. Kitano of Sugiyama Jogakuen University for his critical review of the manuscript. We have benefited from helpful reviews and comments by M. Goldhaber, an anonymous reviewer, and the editor. We are grateful to M. Kusakabe of Okayama University for his encouragement and suggestions throughout the course of this work. Parts of this work were performed using the facilities of Research Reactor Institute, Kyoto University (INNA) and Institute for Study of Earth's Interior, Okayama University (sulfur isotope measurement). 


\section{REFERENCES}

Arai, F., Oba, T., Kitazato, H., Horibe, Y., and Machida, H., 1981. Late Quaternary tephrochronology and paleo-oceanography of the sediments of the Japan Sea. Quat. Res. (Tokyo), 20:209-230.

Brumsack, H.-J., 1980. Geochemistry of Cretaceous black shales from the Atlantic Ocean (DSDP Legs 11, 14, 36 and 41). Chem. Geol., $31: 1-25$.

Chambers, L. A., and Trudinger, P. A., 1979. Microbiological fractionation of stable sulfur isotopes: a review and critique. Geomicrobiol. J., $1: 249-293$.

Cita, M. B., and Grignani, D., 1982. Nature and origin of Late Neogene Mediterranean sapropels. In Schlanger, S. O., and Cita, M. B. (Eds.), Nature and Origin of Cretaceous Carbon-rich Facies: London (Academic Press), 165-196.

Goldhaber, M. B., and Kaplan, I. R., 1974. The sulfur cycle. In Goldberg, E. D. (Ed.), The Sea (Vol. 5): New York (Wiley), 569-655.

1980. Mechanisms of sulfur incorporation and isotope fractionation during early diagenesis in sediments of the Gulf of California. Mar. Chem., 9:95-143.

Kojima, I., Uchida, T., and Iida, C., 1988. Pressurized microwave digestion of biological samples for metal determination. Anal. Sci., 4:211-214.

Koyama, M., Matsushita, R., and Takada, J., 1987. Reactor neutron activation analysis by using multi-elemental comparators: problems of nuclear constants of ${ }^{128} \mathrm{I},{ }^{175} \mathrm{Yb}$ and several other nuclides. J. Radioanal. Nucl. Chem., Articles, 113:199-207.

Leventhal, J. S., 1983. An interpretation of carbon and sulfur relationships in 2Black Sea sediments as indicators of environments of deposition. Geochim. Cosmochim. Acta, 47:133-137.

Masuzawa, T., 1987. Early diagenesis in deep-sea sediments of the Japan Sea: type, controlling factor, and diffusive flux. J. Earth Sci., Nagoya Univ., 35:249-267.

Masuzawa, T., and Kitano, Y., 1983a. Interstitial water chemistry in deep-sea sediments from the Japan Sea. J. Oceanogr. Soc. Jpn., 39:171-184.

1983b. Sulfate reduction and sulfide deposition in deep-sea sediments from the southwestern Japan Sea. J. Oceanogr. Soc. Jpn., 39:251-258.

, 1984. Appearance of $\mathrm{H}_{2} \mathrm{~S}$-bearing bottom waters during the last glacial period in the Japan Sea. Geochem. J., 18:167-172.

Masuzawa, T., and Koyama, M., 1989. Settling particles with positive Ce anomalies from the Japan Sea. Geophys. Res. Lett.. 16:503-506.
Masuzawa, T., Noriki, S., Kurosaki, T., Tsunogai, S., and Koyama, M., 1989. Compositional change of settling particles with water depth in the Japan Sea. Mar. Chem., 27:61-78.

Masuzawa, T., Takamatsu, T., Kawashima, M., and Koyama, M., in press. Environmental change through the last glacial period in the Japan Sea and trace element composition of sediment cores. Tech. Rep. Res. React. Inst., Kyoto Univ.

Nitani, H., 1972. On the deep and bottom waters in the Japan Sea. In Research in Hydrography and Oceanography: Tokyo (Hydrographic Dept. of Japan), 151-201.

Oba, T., Kato, M., Kitazato, H., Koizumi, I., Omura, A., Sakai, T., and Takayama, T., 1991. Paleoenvironmental changes in the Japan Sea during the last 85,000 years. Paleoceanogr., 6:499-518.

Ohmoto, H., Kaiser, C. J., and Geer, K. A., 1990. Systematics of sulphur isotopes in recent marine sediments and ancient sediment-hosted basemetal deposits. In Heebert, H. K., and Ho, S. E. (Eds.), Stable Isotopes and Fluid Processes in Mineralization. Geol. Soc. Aust., Spec. Publ., 23:70-120.

Raiswell, R., and Berner, R. A., 1985. Pyrite formation in euxinic and semieuxinic sediments. Am. J. Sci., 285:710-724.

Sweeney, R. E., and Kaplan, I. R., 1980. Stable isotope composition of dissolved sulfate and hydrogen sulfide in the Black Sea. Mar. Chem., 9:145-152.

Takamatsu, T., and Kawashima, M., 1988. Chemical speciation of sulfur in lake sediments. Abstr. 49th Meeting Jpn. Soc. Anal. Chem., 507-508.

Tamaki, K., Pisciotto, K., Allan, J., et. al., 1990. Proc. ODP, Init. Repts., 127: College Station, TX (Ocean Drilling Program).

Turner, D. R., Whitfield, M., and Dickson, A. G., 1981. The equilibrium speciation of dissolved components in freshwater and seawater at $25^{\circ} \mathrm{C}$ and 1 atmosphere. Geochim. Cosmochim. Acta, 45:855-881.

Vinogradov, A. P., Grinenko, V. A., and Ustinov, V. I., 1962. Isotopic composition of sulfur compounds in the Black Sea. Geochemistry, 10:973-997.

Yanagisawa, F., and Sakai, H., 1983. Thermal decomposition of barium sulfate-vanadium pentoxide-silica glass mixtures for preparation of sulfur dioxide in sulfur isotope ratio measurements. Anal. Chem., 55:985-987.

Date of initial receipt: 3 April 1991

Date of acceptance: 28 November 1991

Ms 127/128B-179 

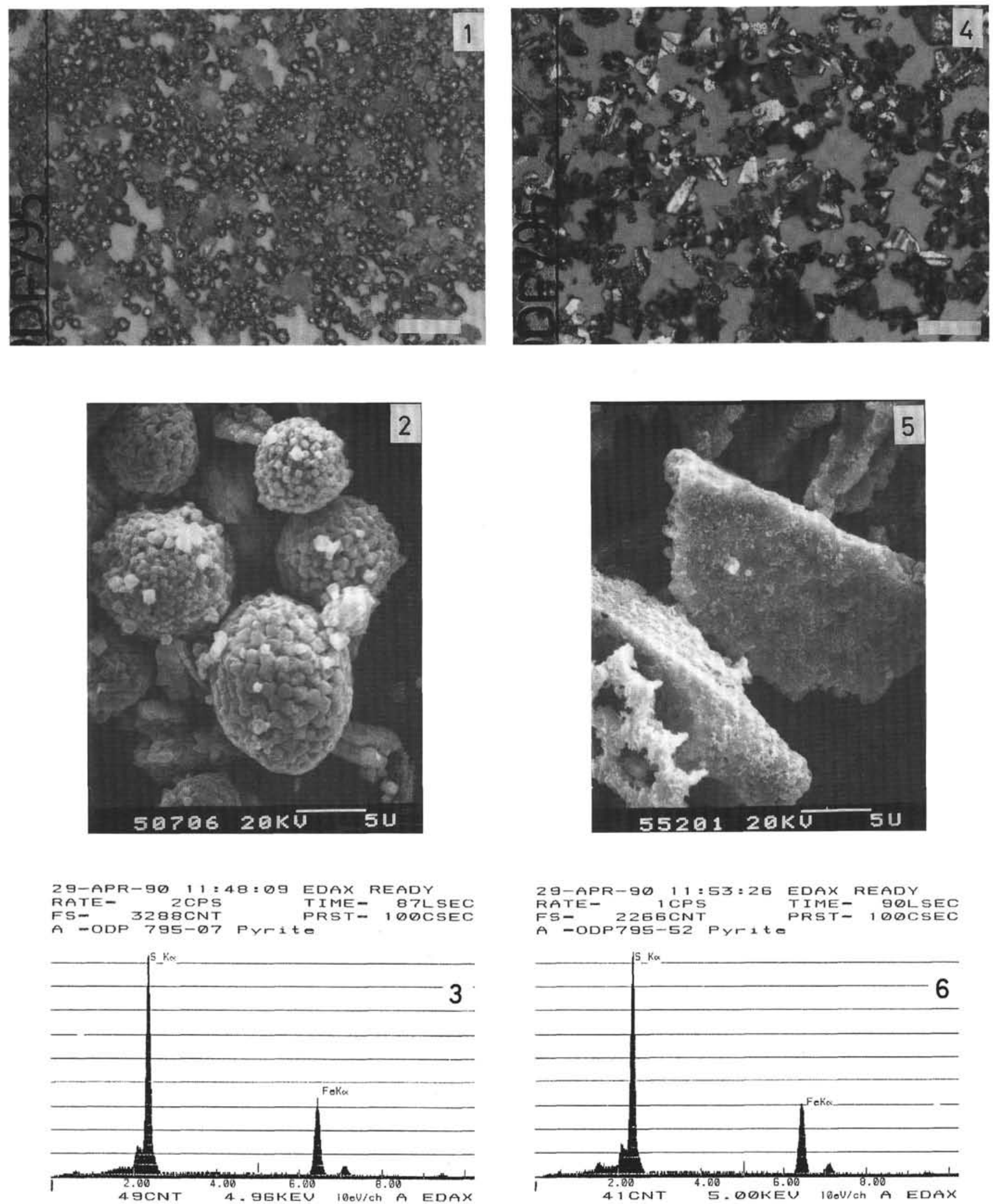

Plate 1. Photomicrographs (scale bar $=50 \mu \mathrm{m})$, SEM images, and EDS spectra of framboidal pyrite spherules isolated from a layer at $61.69 \mathrm{mbsf}\left(1-3 ; \delta^{34} \mathrm{~S}_{\mathrm{CDT}}\right.$ $=-48.3 \%$ oo and angular pyrite grains isolated from a layer at $590.53 \mathrm{mbsf}\left(4-6 ; \delta^{34} \mathrm{~S}_{\mathrm{CDT}}=+11.5 \%\right.$ oo $)$ of Site 795 . 